\title{
Diagenetic Modifications and Reservoir Heterogeneity Associated with Magmatic Intrusions in the Devonian Khyber Limestone, Peshawar Basin, NW Pakistan
}

\author{
Mumtaz M. Shah $\mathbb{D}^{1}$, Saifullah Afridi, ${ }^{1}$ Emad U. Khan, ${ }^{1,2}$ Hamad Ur Rahim $\mathbb{D}^{1,3}$ \\ and Muhammad R. Mustafa ${ }^{4}{ }^{4}$ \\ ${ }^{1}$ Department of Earth Sciences, Quaid-i-Azam University, Islamabad 45320, Pakistan \\ ${ }^{2}$ Department of Geology, Abdul Wali Khan University, Mardan 23200, Pakistan \\ ${ }^{3}$ Earth Sciences Division, Pakistan Museum of Natural History, Islamabad 44000, Pakistan \\ ${ }^{4}$ Department of Civil and Environmental Engineering, Universiti Teknologi PETRONAS, Seri Iskandar 32610, Malaysia
}

Correspondence should be addressed to Mumtaz M. Shah; mshah@qau.edu.pk

Received 9 April 2020; Revised 5 April 2021; Accepted 17 April 2021; Published 3 May 2021

Academic Editor: Enrique Gomez-Rivas

Copyright (c) 2021 Mumtaz M. Shah et al. This is an open access article distributed under the Creative Commons Attribution License, which permits unrestricted use, distribution, and reproduction in any medium, provided the original work is properly cited.

\begin{abstract}
In the present study, an attempt has been made to establish the relationship between diagenetic alterations resulting from magmatic intrusions and their impact on the reservoir properties of the Devonian Khyber Limestone (NW Pakistan). Field observations, petrographic studies, mineralogical analyses, porosity-permeability data, and computed tomography were used to better understand the diagenetic history and petrophysical property evolution. Numerous dolerite intrusions are present in the studied carbonate successions, where the host limestone was altered to dolomite and marble, and fractures and faults developed due to the upwelling of the magmatic/hydrothermal fluids along pathways. Petrographic studies show an early phase of coarse crystalline saddle dolomite (Dol. I), which resulted from Mg-rich hydrothermal fluids originated from the dolerite dykes. Coarse crystalline marble formed due to contact metamorphism at the time of dolerite emplacement. The second phase of dolomitisation (Dol. II) postdates the igneous intrusions and was followed by dedolomitisation, dissolution, and cementation by meteoric calcite. Stable isotope studies likewise confirm two distinct dolomite phases. Dol. I exhibits more depleted $\delta^{18} \mathrm{O}(-15.8$ to $-9.1 \%$ V-PDB $)$ and nondepleted $\delta^{13} \mathrm{C}(-2.05$ to $+1.85 \%$ V $-\mathrm{PDB})$, whereas Dol. II shows a relatively narrow range of depleted $\delta^{18} \mathrm{O}\left(-13.9\right.$ to $-13.8 \%$ ) signatures and nondepleted $\delta^{13} \mathrm{C}(+1.58$ to $+1.89 \%$ V-PDB $)$. Dolomitic marble shows a marked depletion in $\delta^{18} \mathrm{O}$ and $\delta^{13} \mathrm{C}(-13.7$ to $-8.5 \%$ and -2.3 to $1.95 \%$, respectively). The initial phase of dolomitisation (Dol. I) did not alter porosity (5.4-6.6\%) and permeability $(0.0-0.1 \mathrm{mD})$ with respect to the unaltered limestone $(5.6-6.9 \%$; $0.1-0.2 \mathrm{mD})$. Contact metamorphism resulted in a decrease in porosity and permeability $(3.3-4.7 \%$; $0.1 \mathrm{mD})$. In contrast, an increase in porosity and permeability in Dol. II (7.7-10.5\%; 0.8-2.5 mD) and dolomitic marble $(6.6-14.7 \%$; $8.2-13.3 \mathrm{mD})$ is linked to intercrystalline porosity and retainment of fracture porosity in dolomitic marble. Late-stage dissolution and dedolomitization also positively affected the reservoir properties of the studied successions. In conclusion, the aforementioned results reveal the impact of various diagenetic processes resulting from magmatic emplacement and their consequent reservoir heterogeneity.
\end{abstract}

\section{Introduction}

Igneous bodies are widely distributed in frontier basins worldwide, but less attention has been envisaged to better understand the impact of these igneous bodies on hydrocar- bon systems, source rock maturity modification, and alteration of mineralogy and reservoir properties of the associated sedimentary successions (e.g., [1-8]). Recent studies have shown that magmatic intrusions may result in the development of hydrocarbon traps, seals, and migration 
pathways within sedimentary successions, as well as contribute to the thermal maturation of source rocks [1-3, 9-23].

In general, the intrusion of high-temperature magmatic bodies results in contact metamorphism of host carbonate successions, and the associated Mg-rich hydrothermal fluids cause dolomitisation [24-25]. Such dolomitized platform carbonates resulting from hydrothermal fluids have been extensively studied focusing on the source of magnesium, the driving forces for fluids, and the geometry of these geobodies (e.g., [9-18]). In recent studies, it is demonstrated that mafic intrusions may be the source of magnesium, which can result in the formation of high-temperature dolomite [25-26]. These high-temperature dolomites (i.e., hydrother$\mathrm{mal}$ ) are potential hydrocarbon reservoir rocks in many parts of the world, including major reservoirs of Saudi Arabia and Canada (e.g., [13, 25-33]).

In addition, detailed studies have been carried out to investigate the influence of igneous intrusions on the reservoir properties of carbonate rocks [34-38]. However, key parameters controlling the diagenetic alteration of limestone due to their interaction with intrusive bodies are still poorly constrained in the studied formation.

In this study, an attempt has been made to understand the diagenetic alterations (i.e., cementation, dissolution, dolomitization, dedolomitisation, etc.) resulting from the emplacement of high-temperature magmatic intrusions into the Devonian Khyber limestone in the Peshawar basin of NW Pakistan. In the present study, the relationship between the intrusive bodies and the host limestone is investigated with the help of field observations, petrographic studies, and geochemical analyses, which help to better understand the role of diagenetic alterations in the modification of petrophysical properties.

\section{Geological Settings}

In the northern Pakistan part of the Indian Plate, upper Devonian reefal carbonates were deposited in a northward deepening epicontinental sea [35]. Subsequent rifting during the Early Carboniferous [36] was accompanied by the development of NE-striking normal faults and by alkaline magmatism, which continued to the middle Carboniferous. A second phase of magmatism resulted in the emplacement of porphyritic alkaline rhyolites, diabase dikes/sills, and basalts during the Late Carboniferous-Permian, followed by postrift thermal subsidence resulting in marine sedimentation during the Late Triassic [35].

Northward drift of the Indian plate occurred during the Mesozoic and ended up in its convergence with the Eurasian plate during the early Paleocene. This resulted in the formation of regional-scale faults including the Main Karakoram Thrust (MKT), Main Mantle Thrust (MMT), the Panjal Thrust (PT), and the Main Boundary Thrust (MBT), respectively (e.g., [37-48]). The Kohistan-Ladakh batholith (an island arc complex) is sandwiched between the sutured Indian and Eurasian plates (Figure 1). The Main Mantle Thrust (the western extension of the Indus Tsangpo Suture Zone) marks the southern boundary of the batholith and separates it from the Indian plate; the northern boundary with the Eurasian plate is marked by the Main Karakoram Thrust (MKT) (Figure 1; [49]).

The Khyber Range covers the western margin of a metasedimentary Fold-and-Thrust Belt [50] and is located to the north of the Punjal-Khairabad Fault System extending westwards from Gari Habibullah to the Khyber Pass region [51]. The Khyber Range forms a transition zone between the igneous-metamorphic complex in the north and the sedimentary cover in the south [52]. The Khyber Limestone (the focus of this study) is located at the western extremity of the Peshawar Basin (part of the Himalayan Crystalline Nappe-and-Thrust belt) in the Khyber Range, in the foothills of the Main Boundary Thrust (MBT; Figure 1).

According to Khan et al. [34], Paleozoic sedimentary successions exposed in the Khyber Ranges include the Shagai Formation (Cambrian), the Landi Kotal Formation (Ordovician-Silurian), the Ghundai Sar Formation (Silurian-Devonian), and the Khyber Limestone (Devonian). The Khyber Limestone is a platform carbonate which crops out to the NW of the city of Peshawar in an area extending westwards into Afghanistan (Figure 2). Dolerite intrusions of the middle Carboniferous age, ranging in thickness from 10 to $25 \mathrm{~m}$, occur within the Khyber Limestone over an area of about $100 \mathrm{~km}^{2}$ [34].

In the study area, the Khyber Limestone is $\sim 1000 \mathrm{~m}$ thick with very few argillaceous and arenaceous intervals, whereas a maximum thickness of $1300 \mathrm{~m}$ is attained in the type locality near the village of Ali Masjid (Figure 2). This limestone is medium to thick bedded, grey, and medium to fine grained and locally passes into medium to coarse crystalline marble and medium-crystalline, massive dolomite [52]. The northern part of the Khyber Limestone is dissected by basic dykes and sills ( 5-6 $\mathrm{m}$ thick and traceable for hundreds of metres), which occur in the upper part of the formation [54]. The Khyber Limestone has upper and lower faulted contacts with the Landi Kotal and Shagai Formations, respectively [52, 5556].

\section{Materials and Methods}

In the study area, detailed field investigations of igneous intrusions in the Khyber Limestone (Devonian) were carried out. To investigate the effect of igneous intrusion within the host limestone, sampling was performed with particular emphasis on collecting the diagenetic phases identified in the field. Sampling was performed from dyke-limestone contacts to unaltered limestone to collect the various diagenetic phases. In total, 87 samples were collected representing unaltered limestone, its metamorphosed equivalent (marble), and dolomite phases. Petrographic studies of 68 thin sections representing various lithological types were carried out to unravel the diagenetic history of the carbonate rock and to establish a detailed paragenetic sequence. Besides the host limestone, different dolomite facies were distinguished on the basis of crystal boundaries (planar and nonplanar) and crystal size distribution following the classification scheme of Sibley and Gregg [57]. This study was performed using a conventional microscope (Olympus CX31 with a DP-21 camera attachment at the Department of Earth Sciences, 


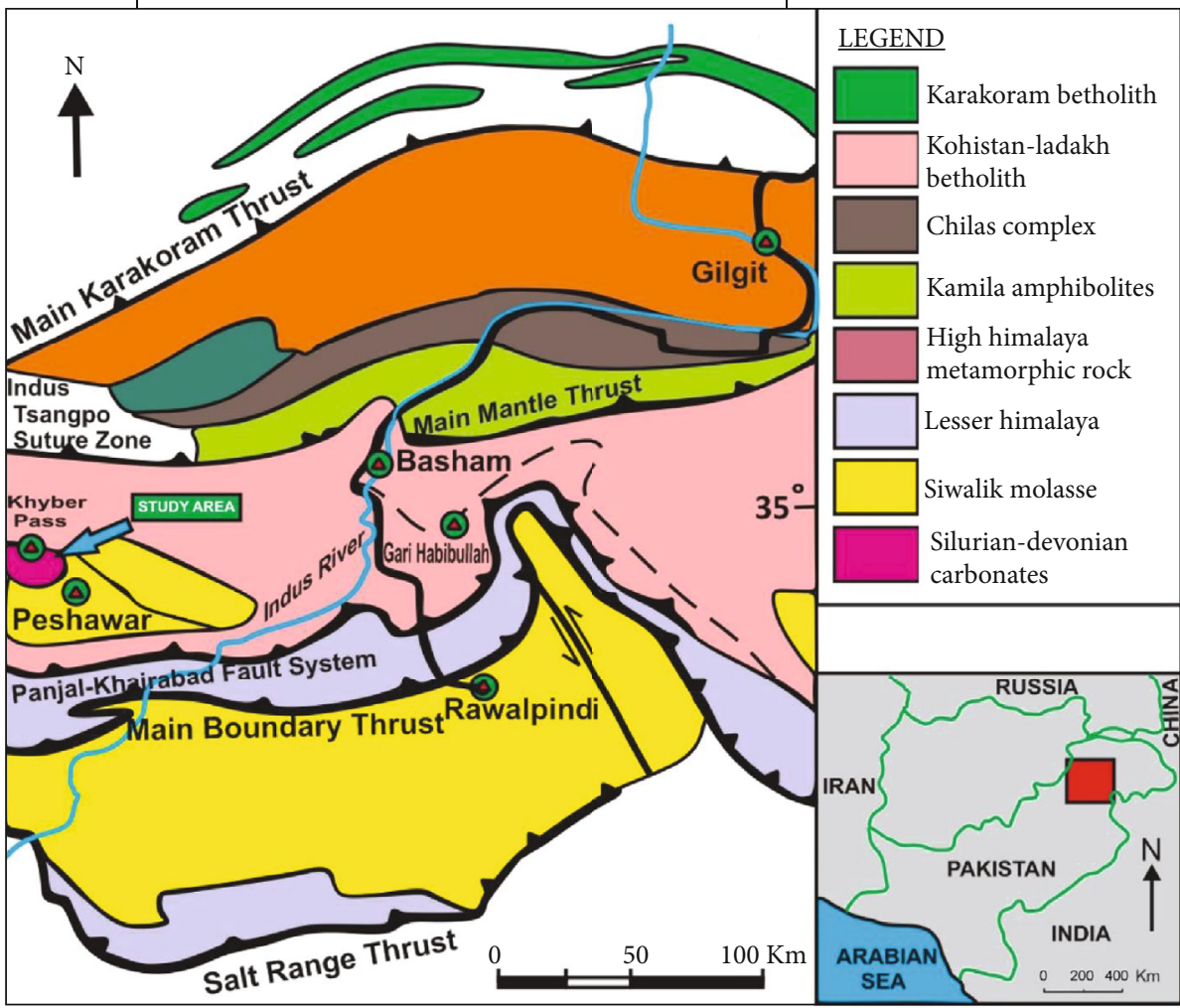

Figure 1: Regional map of tectonostratigraphic units in the northern Himalaya showing the major structural elements and regional-scale thrust faults together with igneous, metamorphic, and sedimentary domains (modified from [53]). The study area NW of Peshawar in northern Pakistan is indicated.

Quaid-i-Azam University, Islamabad). Cathodoluminescence microscopy was carried out at the Institute of Geology, Jagiellonian University, Krakow (Poland), using an optical microscope with a cathodoluminescence stage (CL8100 MK5) with operating conditions of 12 to $17 \mathrm{kV}$ gun potential, 350 to $600 \mu \mathrm{A}$ beam current, and 0.05 Torr vacuum.

Based on petrographic studies, 38 samples representing various phases were selected for X-ray diffraction analyses (XRD) to determine the bulk mineralogical composition. XRD analyses were performed at the Geosciences Advanced Research Laboratory, Geological Survey of Pakistan in Islamabad, where powdered samples were prepared from the whole rock of the selected samples, followed by analyses using PANalytical X'Pert PRO X-ray diffractometer $(\mathrm{Cu}-\mathrm{K} \alpha$ radiation $\sim 45 \mathrm{kV}, 40 \mathrm{~mA})$. The scan speed was set at $0.2^{\circ} \theta \mathrm{min}^{-1}$ and the sampling interval at $0.001^{\circ} \theta$ per step. Furthermore, seventeen samples showing characteristic features of various phases (i.e., host limestone, calcite, and dolomite cements) were collected using a dentist drill for stable isotope studies $\left(\delta^{18} \mathrm{O}\right.$ and $\left.\delta^{13} \mathrm{C}\right)$, whereas analyses were carried out in the Isotope Application Division, Pakistan Institute of Nuclear Science and Technology, Islamabad (Table 1). All stable isotope values are reported in per mil (\%) relative to the Vienna Pee Dee Belemnite (V-PDB) by assigning a $\delta^{13} \mathrm{C}$ value of $+1.95 \%$ and a $\delta^{18} \mathrm{O}$ value of $-2.20 \%$ to NBS19. The carbonate powders were reacted with $100 \%$ phosphoric acid (density $>1.9$; [58]) at $75^{\circ} \mathrm{C}$ in an online car- bonate preparation line (Carbo-Kiel-single sample acid bath) connected to a Finnigan Mat 252 mass spectrometer. Dolomite isotopic composition values are corrected by the fractionation factors given by $[58,59]$.

In order to understand the reservoir heterogeneity in the studied successions, plug scale porosity and permeability analyses and pore network distribution in various diagenetic phases were carried out. The porosity and permeability of 21 unaltered fresh plugs ( $2.8 \mathrm{~cm}$ long and $\sim 1.5 \mathrm{~cm}$ in diameter) were analyzed at the Hydrocarbon Development Institute of Pakistan, Islamabad, using standard laboratory techniques (Core measuring Sampler-100) under a net helium gas pressure of $1000 \mathrm{psi}(6.89 \mathrm{kPa})$. In addition, four samples representing each type, i.e., limestone (LS), dolomarble (DM), saddle dolomite (Dol. I), and dolomite (Dol. II) were selected for computed tomography to better understand the $3 \mathrm{D}$ pore network distribution using a medical CT scanner [60].

\section{Results}

4.1. Field Observations. In the study area in the western Peshawar Basin, the Khyber Limestone in general consists of limestone, dolomite, and marble. Limestone is light to medium grey and medium to thick bedded in the lower part, and the beds decrease in thickness in the upper part (Figure 3). These carbonates are intruded by 10 to $15 \mathrm{~m}$ thick, irregular-shaped dolerite dykes (Figures 3(a) and 3(b)). The 


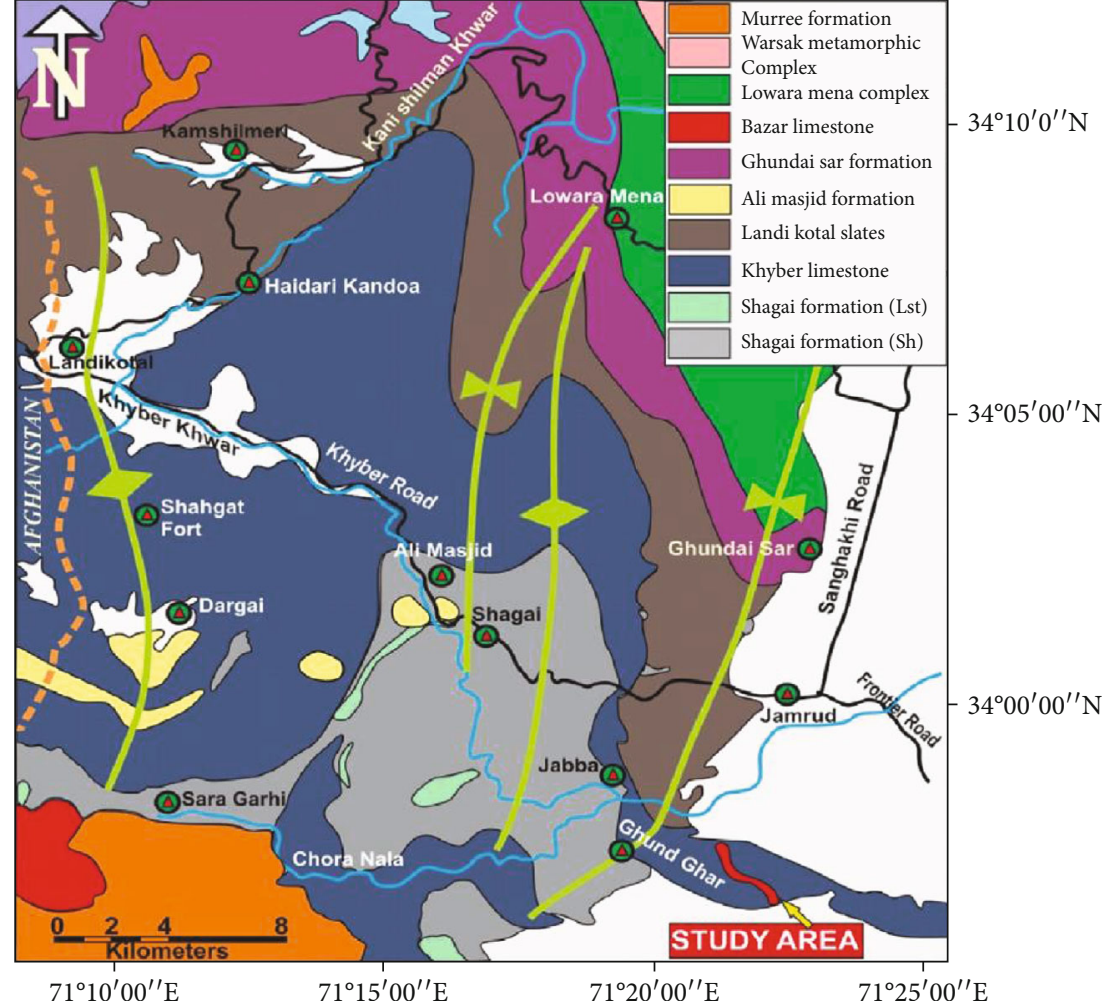

(a)

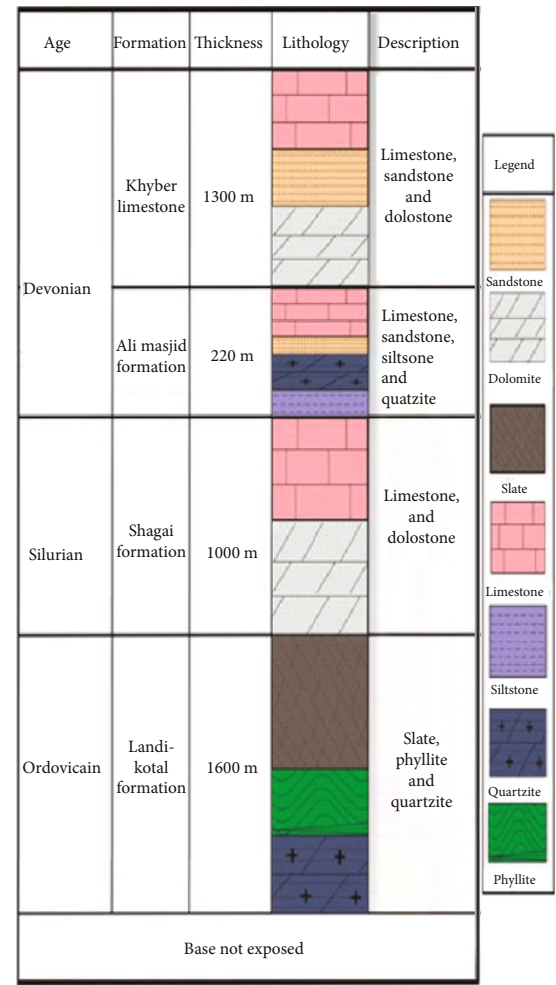

(b)

Figure 2: (a) Geological map of the area NW of Peshawar, showing the location of the studied section where igneous intrusions crosscut the Khyber Limestone. (b) Stratigraphic column showing lithological successions of formations exposed in the study area (modified from Khan et al. [34]).

intrusions occur mostly in the lower and middle parts of the Khyber Limestone, and no intrusions are reported in the upper part (Figures 3(a) and 3(b)). Transformation of the limestone into marble and progressive dolomitisation occurs near the intrusive bodies (Figure 3(d)). Contact metamorphism resulted in the formation of marble at the margins between the limestone and the intrusions, and the intensity of metamorphism decreases away from the intrusive body (Figure 3(b)). The contact between the intrusive bodies and the surrounding steeply dipping metamorphosed limestone (marble) is irregular (Figures 3(a) and 3(b)). In addition, a high density of fractures is observed in the intrusive body as well as in the surrounding marble units (Figure 3(b)). Isolated, unaltered blocks of limestone contain pore-filled dark brown dolomite, which has a friable texture (Figures 3(d) and 4(a)). Detailed investigations showed two distinct dolomite types, which include the following: (i) light brown massive dolomite (Dol. I), exhibiting replacive dolomite texture and observed as isolated clasts in contact with host limestone and postdated by magmatic rocks (Figures 4 (b) and 4(c) and (ii) medium to dark brown, fracture-filled dolomite (Dol. II), which mostly occurs within dissolution cavities and fractures in the metamorphosed limestone (Figure 4(d)).

4.2. Petrographic Studies. Various facies exhibiting depositional and diagenetic imprints are petrographically identified. These include (i) host limestone, (ii) nonplanar dolomite (Dol. I), (iii) dolomarble, and (iv) planar dolomite (Dol. II) (Figures 5-6).

(i) Host Limestone. The Khyber Limestone mostly consists of coralline, wacke- to packstone facies, which contain abundant fractures and vugs. The fractures are filled with fracture-filling dolomite (Figures 4(c) and $5(\mathrm{a}))$.

(ii) Nonplanar Dolomite (Dol. I). Such matrix dolomites are coarse crystalline, nonplanar, and anhedral in appearance with crystal sizes ranging from 1000 to $5000 \mu \mathrm{m}$, showing undulose extinction and curved crystal boundaries (like horse's saddle) and therefore termed "saddle dolomite" (Figure 5(b)). Dol. I shows dull luminescence with occasional bright red luminescence bands (Figures 5(c) and 5(d)). Intercrystalline pore spaces are limited and are occluded by clayey material (Figures 5(b) and 5(c)). In addition, twinned calcite represented by grey and dark blue colored bands is also observed in limestone (Figure 5(e)). Partial modification of nonplanar saddle dolomite (Dol. I) into twinned calcite is evident which shows its transformation into marble (Figure 5(f)).

(iii) Dolomarble. It mostly consists of white to off-whitecolored metamorphosed calcite with occasional brown-colored dolomite cement mostly associated 
TABle 1: Data set of various diagenetic phases showing mineral composition in percentage, carbon and oxygen isotopes, and porosity/permeability data. LS: limestone, DM: dolomitic marble, M: marble, CC: calcite, Dedol: dedolomite.

\begin{tabular}{|c|c|c|c|c|c|c|c|c|c|}
\hline \multirow[b]{2}{*}{$\begin{array}{l}\text { Sr. } \\
\text { No. }\end{array}$} & \multirow[b]{2}{*}{$\begin{array}{c}\text { Facies } \\
\text { type }\end{array}$} & \multicolumn{3}{|c|}{ Mineralogy } & \multicolumn{3}{|c|}{ Isotope analyses } & \multicolumn{2}{|c|}{ Reservoir properties } \\
\hline & & Calcite (\%) & Dolomite (\%) & Others (\%) & $\begin{array}{c}\delta^{18} \mathrm{O} \\
(\mathrm{V}-\mathrm{PDB})\end{array}$ & $\begin{array}{c}\delta^{18} \mathrm{O} \\
(\mathrm{SMOW})\end{array}$ & $\begin{array}{c}\delta^{13} \mathrm{C} \\
(\mathrm{V}-\mathrm{PDB})\end{array}$ & Porosity (\%) & Permeability $(\mathrm{mD})$ \\
\hline 1 & LS & 92 & & Quartz (8) & & & & & \\
\hline 2 & LS & 100 & 0 & & -4.57 & 26.2 & 1.49 & 6.18 & 1.5 \\
\hline 3 & LS & 91 & 0 & Quartz (9) & -5.87 & 24.86 & 1.85 & 5.63 & 2.8 \\
\hline 4 & LS & 90 & & Quartz (10) & & & & 6.88 & 2.5 \\
\hline 5 & Dol. I & & 97 & Quartz (3) & -14.42 & 16.04 & 1.85 & & \\
\hline 6 & Dol. I & & 77 & Quartz (23) & -9.1 & 21.53 & -2.05 & 6.56 & 0.6 \\
\hline 7 & Dol. I & & 82 & Quartz (18) & & & & 5.79 & 0.1 \\
\hline 8 & Dol. I & & 79 & Quartz (21) & & & & & \\
\hline 9 & Dol. I & & 93 & Quartz (7) & & & & 5.35 & 0.1 \\
\hline 10 & Dol. I & & & & -15.83 & 14.6 & 2 & & \\
\hline 11 & Dol. I & & 90 & Quartz (10) & & & & & \\
\hline 12 & M & 56 & 0 & Ankerite (36); Quartz (8) & & & & 4.66 & 0.5 \\
\hline 13 & M & 88 & 0 & Quartz (12) & & & & 3.25 & 0.9 \\
\hline 14 & M & 98 & 2 & & & & & & \\
\hline 15 & M & 100 & & & & & & & \\
\hline 16 & M & 85 & & Quartz (15) & -9.15 & 21.48 & -1.98 & & \\
\hline 17 & M & 93 & 0 & Quartz (7) & -8.78 & 21.86 & -2.25 & 3.76 & 0.8 \\
\hline 18 & Dol. II & & 100 & & & & & 9.02 & 1.1 \\
\hline 19 & Dol. II & 95 & 5 & & & & & 9.31 & 2 \\
\hline 20 & Dol. II & 88 & 12 & & & & & 7.65 & 2.5 \\
\hline 21 & Dol. II & 3 & 97 & & -13.93 & 16.55 & 1.58 & 9.91 & 1.1 \\
\hline 22 & Dol. II & 9 & 91 & & & & 1.89 & & \\
\hline 23 & Dol. II & 4 & 96 & & -13.76 & 16.72 & 1.89 & 8.07 & 2 \\
\hline 24 & Dol. II & & & & & & & 10.48 & 1.8 \\
\hline 25 & $\mathrm{DM}$ & 75 & 25 & & & & & 8.21 & 9.4 \\
\hline 26 & $\mathrm{DM}$ & 71 & 29 & & -8.51 & 22.14 & -2.42 & 7.56 & 8.2 \\
\hline 27 & $\mathrm{DM}$ & 78 & 22 & & & & & & \\
\hline 28 & $\mathrm{DM}$ & 85 & 15 & & & & & & \\
\hline 29 & $\mathrm{DM}$ & 71 & 29 & & -8.63 & 22.01 & -2.58 & 13.2 & 13.3 \\
\hline 30 & $\mathrm{DM}$ & 76 & 24 & & & & & & \\
\hline 31 & $\mathrm{DM}$ & 73 & 27 & & -8.47 & 22.18 & -2.48 & & \\
\hline 32 & $\mathrm{DM}$ & 71 & 29 & & & & & 12.9 & 11.9 \\
\hline 33 & $\mathrm{DM}$ & 65 & 35 & & -9.64 & 20.97 & -2.33 & & \\
\hline 34 & $\mathrm{DM}$ & 89 & 19 & & & & & & \\
\hline 35 & $\mathrm{DM}$ & 81 & 11 & & & & & 6.66 & 8.8 \\
\hline 36 & $\mathrm{DM}$ & & 94 & Pentlandite (6) & -13.69 & 16.8 & 1.85 & 14.7 & 12.8 \\
\hline 37 & $\mathrm{DM}$ & 73 & 27 & & -8.78 & 21.86 & -2.69 & & \\
\hline 38 & $\mathrm{CC}$ & 91 & 9 & & -6.11 & 24.61 & -7.12 & - & - \\
\hline 39 & Dedol. & & 88 & Quartz (12) & -6.41 & 24.3 & -5.14 & & \\
\hline
\end{tabular}



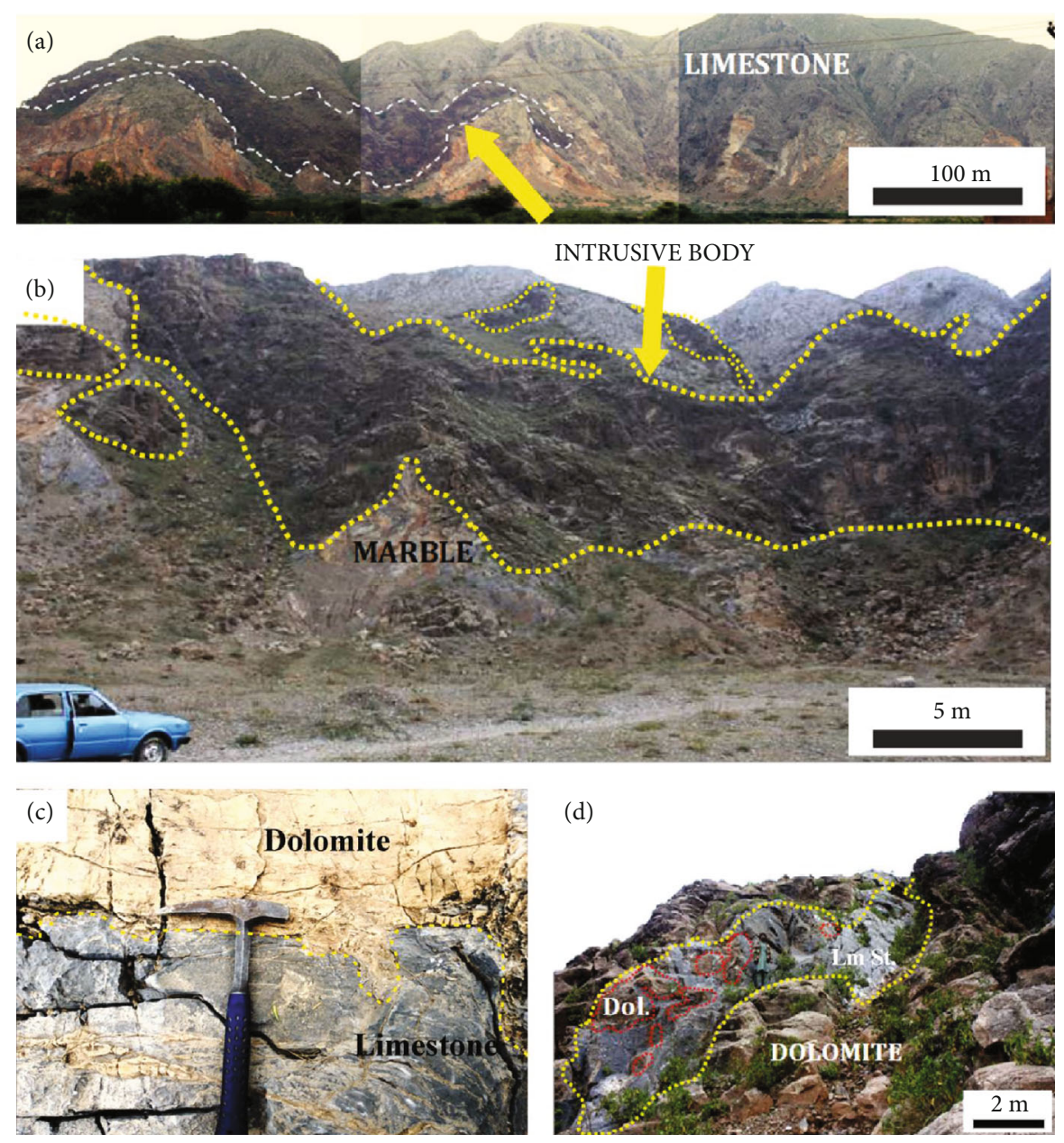

FIGURE 3: Field photographs of host rock (limestone) and igneous intrusions in the study area. (a) Panoramic view of the outcrop showing the distribution of dolerite intrusions in the Khyber Limestone succession shown by white dotted line. (b) Close-up view of a dolerite dyke intrusion in the Khyber limestone marked by yellow dotted line. Note that the marble is formed due to contact metamorphism phenomena. (c) Sharp contact between limestone-dolomite units in the formation. (d) Isolated block of limestone shown by yellow dotted line within the dolerite intrusion, surrounded by light brown-colored dolomite.

with fracture and vugs fillings (Figure 5(e)). Petrographically, twinned calcite is typically associated with the metamorphism and is replacing nonplanar dolomite (Dol. I) (Figure 5(f)).

(iv) Planar Dolomite (Dol. II). Medium to coarse crystalline, planar dolomite mostly occurs as thick (tens of $\mathrm{cm}$ ) fracture and vug fillings in the preexisting metamorphosed limestone (i.e., twinned calcite) and Dol. I (Figures 6(a) and 6(b)). Petrographic observations reveal that Dol. II presents a dark brown color with distinguishable dark and bright zones present in it (Figures 6(a) and 6(b)). It mostly postdates twinned calcite, which is in contact with nonplanar saddle dolomite (Dol. I; Figure 6(a)). Cathodoluminescence analyses show that dolomite presents a bright red luminescence color, which makes it easily distinguishable from Dol. II (Figures 6(b) and 6(c)). A progressive change in luminescence from bright red to dull orange color is associated with dolomite calcitization (Figures 6(c) and 6(d)). Dol. II mostly occurs as fracture/cavity fillings in marble, while some intercrystalline pore spaces are present (Figure 6(e)). Large dolomite crystals may however extend into pore spaces (Figure 6(e)). Overgrowths of white-colored dolomite cement around Dol. II indicate late-stage dolomite cementation (Figure 6(e)). Finally, dissolution is restricted to dark-colored bands in dolomite crystals, as shown in Figure 6(f).

(v) Dedolomite. These are rusty brown-colored calcite, mostly present on the weathered surfaces. It appears to be rhombohedral shaped under polarized light, whereas to nonluminescent mottled appearance under CL (Figures 6(d) and 6(f)).

4.3. Mineralogical Analysis and Isotopic Signatures. Quantitative mineralogical composition of matrix dolomite and distinct phases of pore-filling cements help to better 


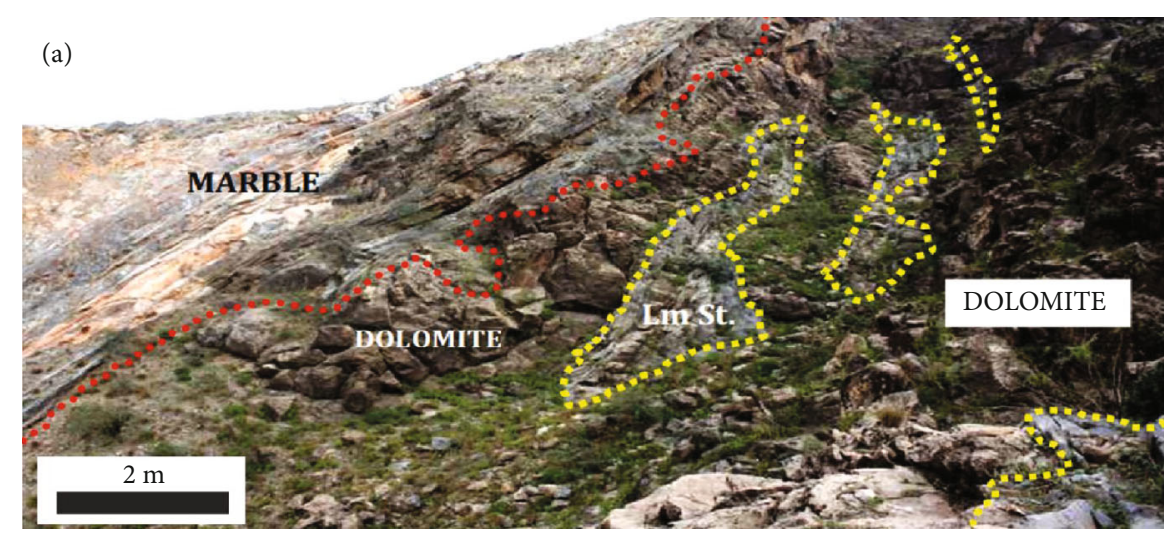

(a)

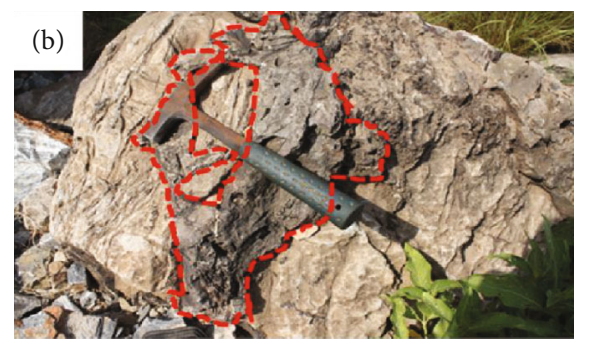

(b)

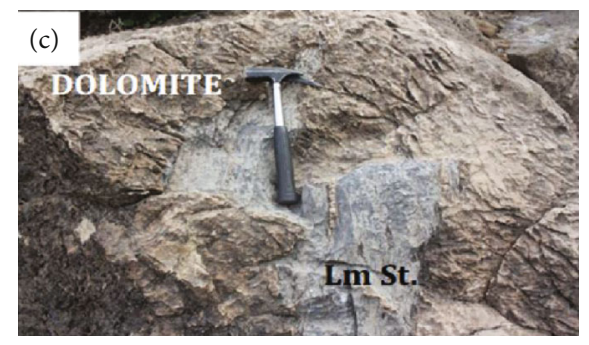

(c)

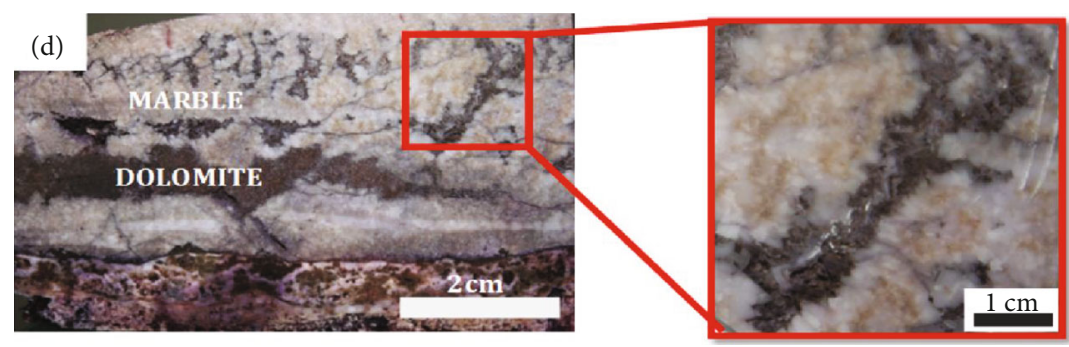

(d)

Figure 4: Field photographs of major diagenetic phases (marble, dolomites) in the study area. (a) Contact relationships between limestone/marble with igneous intrusion and dolomite. Note that isolated blocks of limestone frequently occur within the succession. (b) Black igneous dyke material in contact with medium grey dolomite. (c) Irregular contact between light grey limestone and dark brown dolomite. (d) Cut slab showing dark brown, sugary textured dolomite Dol. II in contact with light brown dolomitic marble; inset shows a close-up view of the pore-filling dolomite (Dol. II) and dolomitic marble (DM). Lm St: limestone.

understand the probable source of the identified minerals, as well as the porosity/permeability distribution in the analyzed samples. Nonplanar dolomite (Dol. I) forms a major part of the whole rock geochemistry in the thirty-eight analyzed samples (Table 1; Figures 7(a) and 7(b)), whereas palygorskite mostly occurs in the intercrystalline pore spaces of dolomite (Figure 5(c)). Besides this, other accessary minerals, which include ankerite and diopside, occur in association with dolomite (Figure 7(c)).

Seventeen samples representing the characteristic features of various diagenetic phases (i.e., host limestone, dolomite (Dol. I, Dol. II), and dolomitic marble) were selected for stable isotope studies $\left(\delta^{18} \mathrm{O}\right.$ and $\left.\delta^{13} \mathrm{C}\right)$. The correlation of these phases is done with known seawater signatures of Devonian derived from Veizer et al. [61]. The approximate values of $\delta^{18} \mathrm{O}$ ranges from -7.32 to $-3.98 \%$ V-PDB, whereas $\delta^{13} \mathrm{C}$ signatures varies from -2.01 to $+3.14 \%$ o $\mathrm{PDB}$, respectively (Figure 8).
In the studied samples, limestone and various diagenetic phases affected by igneous intrusions show a broad range of depleted $\delta^{18} \mathrm{O}$ values ( -15.83 to $\left.-6.11 \% \mathrm{~V}-\mathrm{PDB}\right)$, while $\delta^{13} \mathrm{C}$ values ( -2.7 to $+2.5 \%$ V-PDB) are close to those reported for carbonates precipitated from Devonian seawater [61]. The unaffected limestone showed $\delta^{18} \mathrm{O}$ signatures ranging from -5.87 to $-4.57 \% \mathrm{~V}$-PDB (Figure 8 and Table 1 ). The $\delta^{13} \mathrm{C}$ values range from +1.49 to $+1.85 \%$ o $\mathrm{V}-\mathrm{PDB}$. Both $\delta^{18} \mathrm{O}$ and $\delta^{13} \mathrm{C}$ values are within the range of Devonian seawater signatures (Figure 8; Table 1). Coarse crystalline, replacive nonplanar dolomite (Dol. I) shows $\delta^{18} \mathrm{O}$ signatures ranging from -15.83 to $-9.1 \%$ V-PDB, exhibiting depleted values compared to the marine signatures (Figure 8 and Table 1). The $\delta^{13} \mathrm{C}$ values ranging from -2.05 to $+1.85 \%$ o $\mathrm{V}-\mathrm{PDB}$ are within the range of seawater signatures (Figure 8; Table 1). The marbles also show considerable depletion in $\delta^{18} \mathrm{O}$ values (i.e., -9.15 to $-8.78 \% \mathrm{~V}$-PDB), while the $\delta^{13} \mathrm{C}$ values ranging from $(-2.25$ to $-1.98 \%$ o $)$ are slightly depleted with respect to 


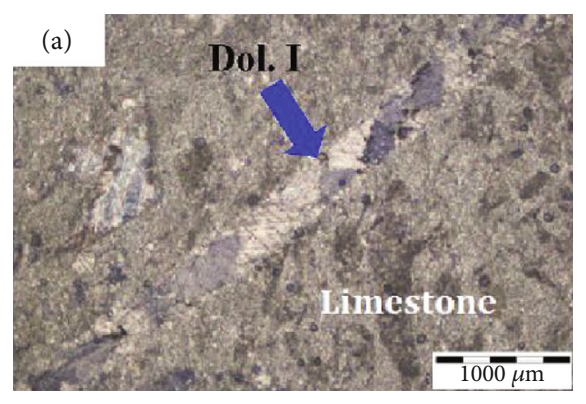

(a)

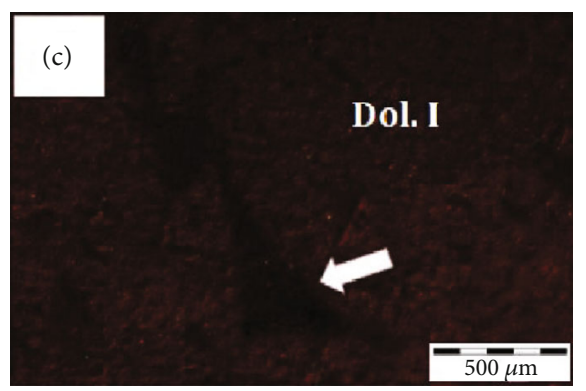

(c)

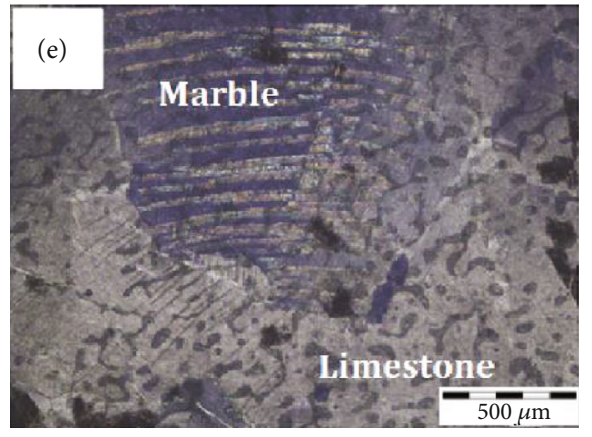

(e)

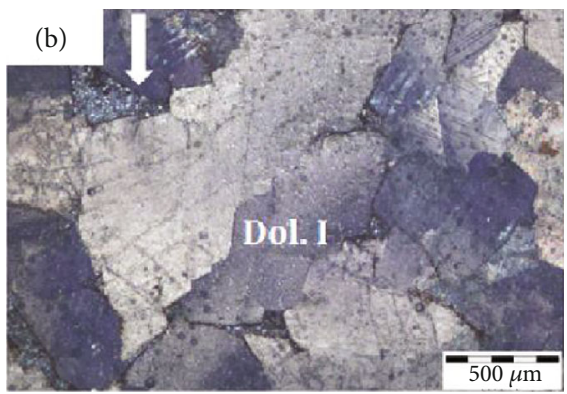

(b)

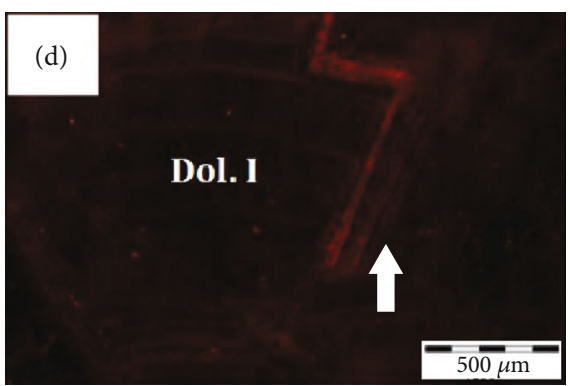

(d)

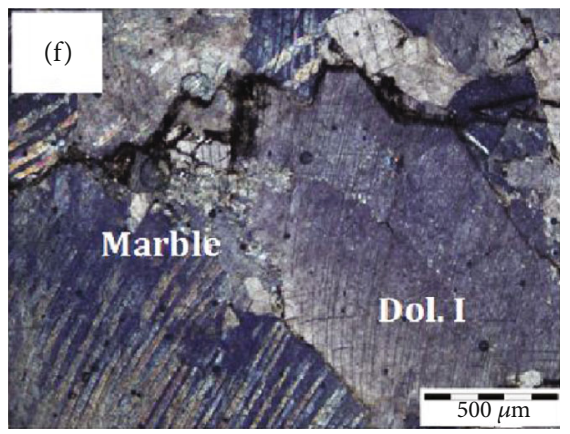

(f)

FIgURE 5: Petrographic studies of the Khyber Limestone showing various diagenetic phases. (a) Crossed-polarized photomicrograph of the coralline limestone (wacke- to packstone) containing fracture-filling dolomite (Dol. I) shown by blue arrow (b) Medium to coarse crystalline (Dol. I) exhibiting undulose extinction typical of saddle nature; clay minerals filling the intercrystalline pore spaces shown by white arrow. (c, d) Cathodoluminescence (CL) photomicrograph showing dull luminescent dolomite (Dol. I); pore-filling detrital clays are nonluminescent (arrow). (e) Partial replacement of coralline limestone with coarse-grained marble in the upper part while the limestone is in the lower part. (f) Partial to complete replacement of coarse crystalline, nonplanar dolomite by marble.

the Devonian seawater (Figure 8; Table 1). The cavity-filling dolomite cements (Dol. II) exhibit depleted $\delta^{18} \mathrm{O}$ isotope signatures (i.e., -13.93 to $-13.76 \%$ V $-\mathrm{PDB}$; Figure 8 ). The $\delta^{13} \mathrm{C}$ values (i.e., +1.58 to $+1.89 \%$ V-PDB) are within the Devonian seawater signature area (Figure $8(\mathrm{a})$ ). The dolomitic marbles (DM) have $\delta^{18} \mathrm{O}$ values ranging from -13.69 to $-8.47 \%$ V-PDB (Figure 8 and Table 1 ), while $\delta^{13} \mathrm{C}$ values range from -2.69 to $+1.85 \% \mathrm{~V}$-PDB. The $\delta^{18} \mathrm{O}$ values are significantly depleted with respect to the marine signatures, and $\delta^{13} \mathrm{C}$ values are slightly depleted compared to seawater signatures (Figure 8; Table 1). Furthermore, the calcite (CC) and dedolomite (Dedol.) represent depleted O/C signatures, which are $-6.11 \%$ V-PDB $\left(\delta^{18} \mathrm{O}\right)$ and $-7.12 \%$ V-PDB $\left(\delta^{13} \mathrm{C}\right)$ for calcite $(\mathrm{CC})$ and $-6.41 \% \mathrm{~V}-\mathrm{PDB}\left(\delta^{18} \mathrm{O}\right)$ and $-5.14 \%$ V $-\mathrm{PDB}\left(\delta^{13} \mathrm{C}\right)$ for dedolomite (Dedol.), respectively.

\subsection{Reservoir Properties}

(i) Petrographic and Porosity-Permeability Analyses. Limestone samples analyzed for porosity and permeability studies exhibit negligible porosity as the pore space (i.e., fractures) is filled with calcite cement (Figure 9). The measured porosity and permeability values of the precursor limestone range from 5.6 to $6.9 \%$ and 0.1 to $0.3 \mathrm{mD}$, respectively (Figure 9). Coarse crystalline, nonplanar dolomite (Dol. I) occurs as a replacive phase with a narrow range of porosity and permeability (i.e., 5.3-6.6\%; 0.0$0.1 \mathrm{mD}$ ) (Figures 9 and 10(a)). Intercrystalline pore spaces in Dol. I are mostly filled with detrital clays, which also reduce porosity (Figures 9 and $6(\mathrm{~b})$ ). Marble exhibits low porosity $(3.25-4 \%)$ and permeability values $(0.5-0.9 \mathrm{mD})$, 


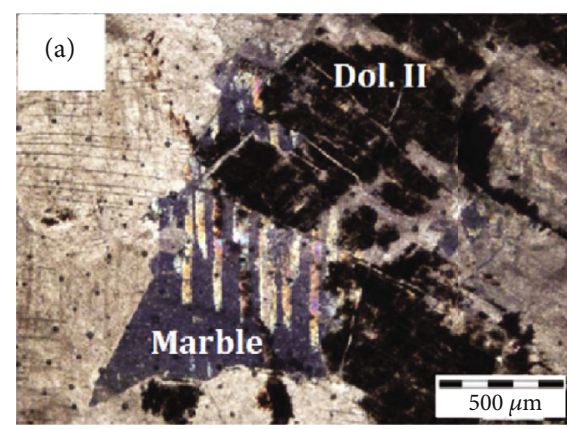

(a)

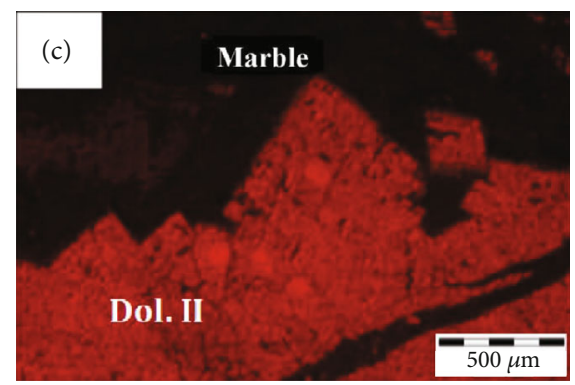

(c)

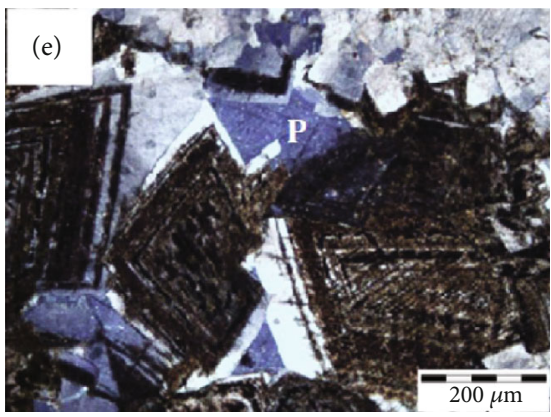

(e)

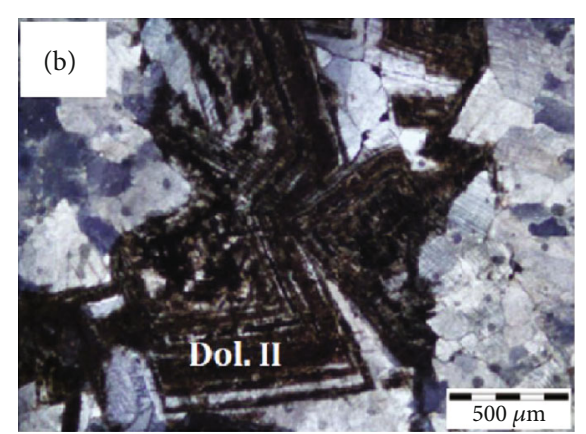

(b)

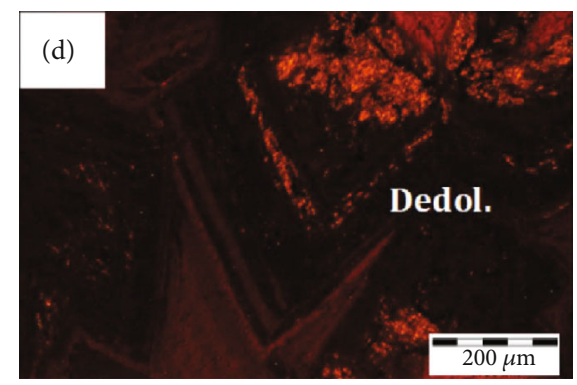

(d)

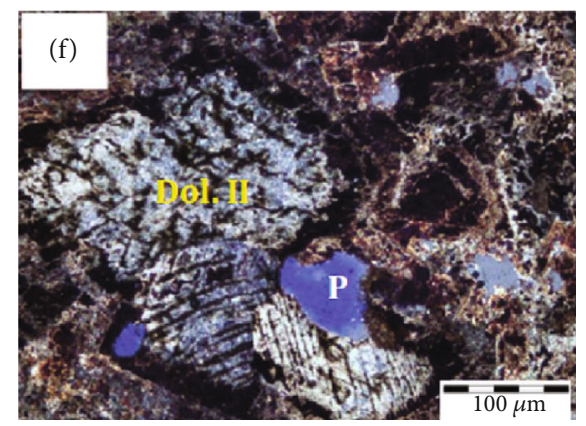

(f)

FIGURE 6: Petrographic studies of the Khyber Limestone showing various diagenetic phases. (a) Crossed-polarized photomicrograph showing brown color medium to coarse crystalline, dolomite in contact with marble. Note that the Dol. II postdates the marble. (b) Crossed-polarized photomicrograph showing pore-filling dolomite Dol. II in medium- to coarse-grained marble. (c) Cathodoluminescence photomicrograph showing bright red luminescence of dolomite (Dol. II), and marble with dull orange luminescence. (d) Cathodoluminescence photomicrograph showing progressive dedolomitisation is indicated by the change from bright red luminescent dolomite (Dol. II) to dull orange-colored calcite. (e) Crossed-polarized photomicrograph showing intercrystalline porosity (P) in the Dol. II. The crystals of Dol. II are in contact with medium- to coarse-grained marble. (f) Cross-polarized photomicrograph showing calcitization and dissolution porosity (P) in Dol. II.

which may be due to recrystallization of the original limestone and occlusion of the pore space (Figure 10(a)). Dolomitic marble shows considerably higher porositypermeability values $(6.7-14.7 \%$ and $0.8-13.3 \mathrm{mD})$, contrasting with preexisting marble with lower porositypermeability values (Figures 9 and 10(a)). Mediumcrystalline pore-filling dolomite (Dol. II) shows relatively high dissolution porosity and low permeability due to its corrosive nature, which makes it highly porous but not permeable (Figures 6 and 10(a)). Pore-filling dolomite (Dol. II) contains porosity values ranging from 7.6 to $10.5 \%$ and low permeability values $(0.1-0.2 \mathrm{mD})$ (Table 1$)$.

In some samples where dolomite is abundant, the porosity ranges from 6.2 to $13.2 \%$ (Figure $10(\mathrm{~b})$ ). The pres- ence of twinned calcite occludes the pore space and hence decreases porosity (Figure 5). In the studied samples, containing low permeability values with correspondingly high porosity values is due to late-stage calcite and clay minerals, which were precipitated in the pore spaces and in fractures to form veins (Figures 5, 6(a), and 6(b)).

(ii) Computed Tomography (CT). In order to better constrain the distribution and interconnectivity of the pore network, the precursor limestone and selected diagenetic phases, i.e., dolomite Dol. I (coarse crystalline, saddle nature), dolomarble (dolomite marble), and dolomite Dol. II (pore-filling), were examined (Figure 11). The results show that the precursor limestone samples exhibit lower porosity (lack of dark spots) compared to dolomite (Dol. 


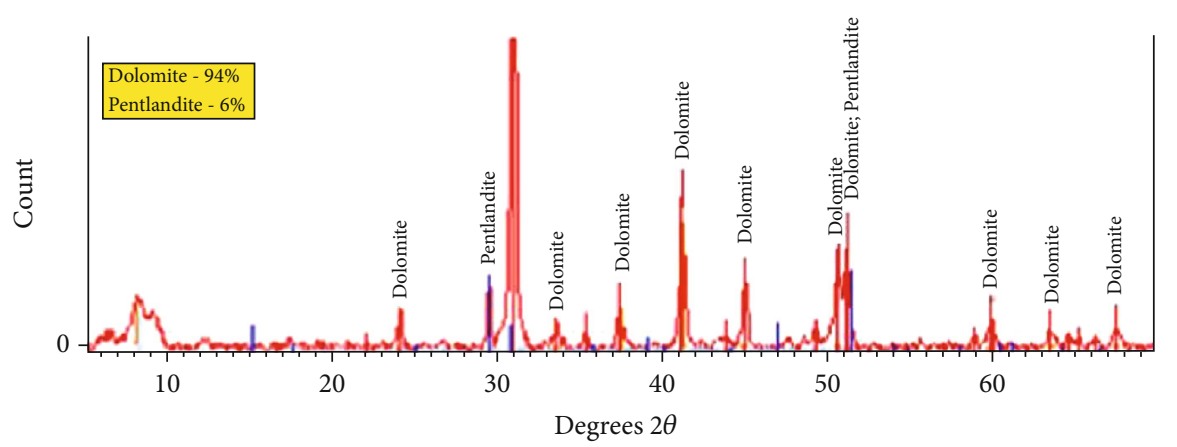

(a)

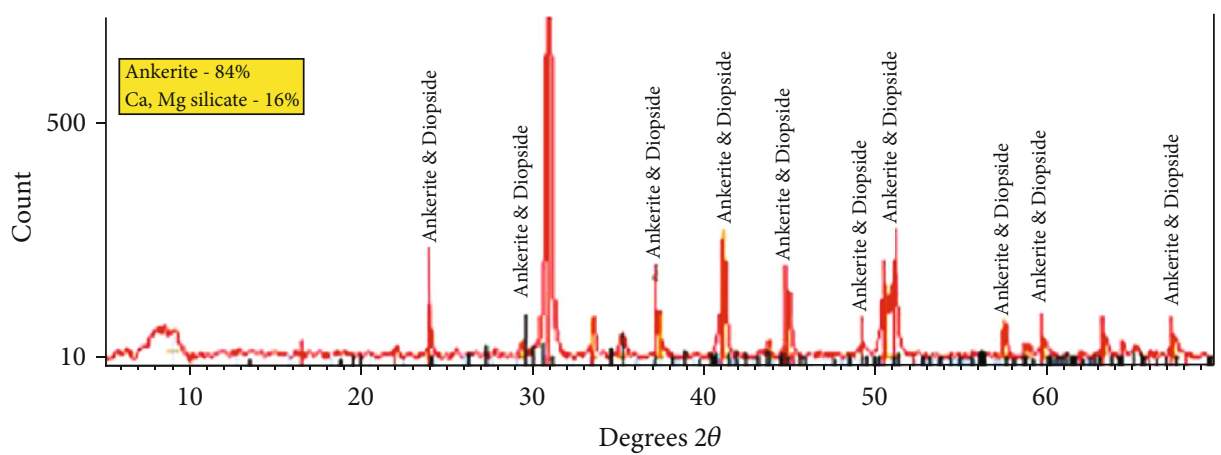

(b)

FIGURE 7: X-ray diffractograms showing different mineral constituents within the studied carbonate succession. The major minerals observed are dolomite and some other minor constituents (i.e., pentlandite, ankerite, and diopside) in the studied samples. The presence of hightemperature minerals shows the emplacement of igneous activity.

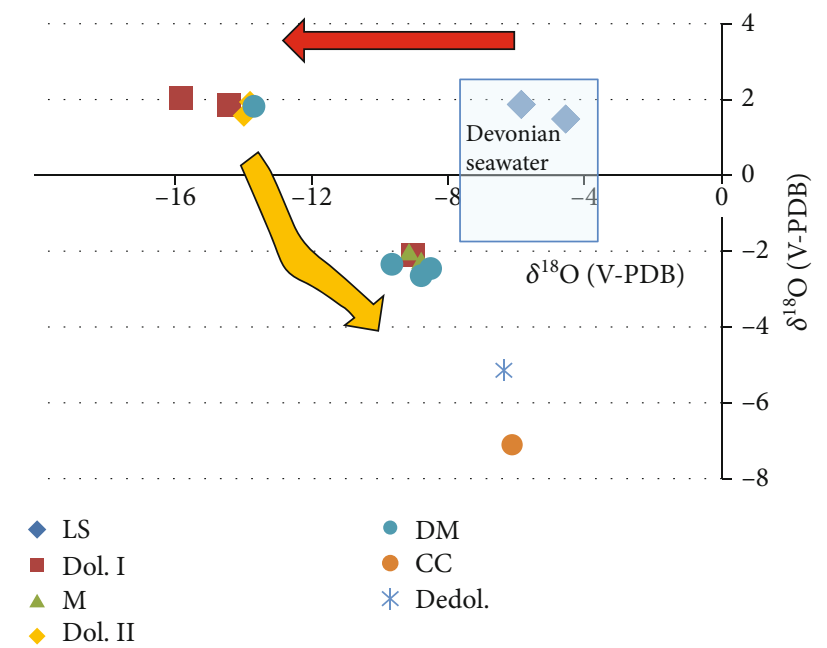

Figure 8: Cross-plot of $\delta^{18} \mathrm{O}(\mathrm{V}-\mathrm{PDB})$ versus $\delta^{13} \mathrm{C}(\mathrm{V}-\mathrm{PDB})$ of limestone (LS), dolomite (Dol. I and Dol. II), marble (M) and dolomitic marble (DM). Dashed blue box indicates the range of Devonian seawater according to [61]. Red arrow shows the temperature effect while the yellow arrows show the effect of surficial fluids.

II) and dolomarble (relatively high concentrations of dark spots) in transversal views of selected samples (Figure 11). The amount of pore space in dolomite (Dol. II) and dolomarble is higher compared to the above-mentioned phases, whereas saddle dolomite (Dol. I) shows very few pore spaces (negligible dark spots; Figure 11).

In the cross-sectional and $3 \mathrm{D}$ views, different phases exhibit diagnostic pore network connectivity (Figure 11). Limestone exhibits less fracture-related linear open spaces and low microfracture development, whereas dolomarble and Dol. II show intercrystalline pore spaces having a high rate of pore interconnectivity linked to associated dolomite Dol. II, hence exhibiting relatively high permeability (Figure 11).

\section{Discussion}

The studied Devonian Khyber Limestone has been extensively altered by hydrothermal processes. Field and petrographic studies reveal that the magmatic intrusions are emplaced within the carbonate succession into the middle and bottom parts of the sedimentary unit. As discussed earlier, the area was subjected to rifting and associated normal faulting during the middle Carboniferous, and this resulted in alkaline magmatism $[35,36]$. These normal faults were the most favorable conduits for channelizing hydrothermal fluids [13,25] (Figures 3-6). The occurrence of these hydrothermal dolomites in association with intrusive igneous bodies along the normal faults suggests its origin from the same hydrothermal fluids. Field observations show sharp contacts between the limestone and the intrusive bodies. The presence 


\begin{tabular}{|c|c|c|c|c|}
\hline FACIES & Limestone & Dol. I & Dolomarble & Dol. II \\
\hline 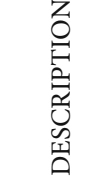 & $\begin{array}{c}\text { Coraline limestone ranging } \\
\text { from wack- to packstone with } \\
\text { occasional dissolution } \\
\text { porosity, which ranges from } \\
6-7 \%\end{array}$ & $\begin{array}{l}\text { Coarse crystalline, white } \\
\text { colored saddle dolomite with } \\
\text { intercrystalline pore spaces. } \\
\text { Measured porosity is } 5-7 \%\end{array}$ & $\begin{array}{l}\text { Marble containg patially } \\
\text { altered dolomite. Crystal } \\
\text { growth of dolomite is } \\
\text { evident. Porosity ranges from } \\
7-15 \%\end{array}$ & $\begin{array}{c}\text { Medium crystalline } \\
\text { dolomite with dissolution } \\
\text { porosity }(7-11 \%) \text {. Pore } \\
\text { spaces are later filled by } \\
\text { calcite. }\end{array}$ \\
\hline 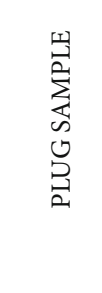 & & & $1 \mathrm{~cm}$ & $1 \mathrm{~cm}$ \\
\hline 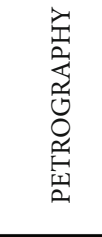 & $\frac{3}{2000}$ & $=_{500}$ & 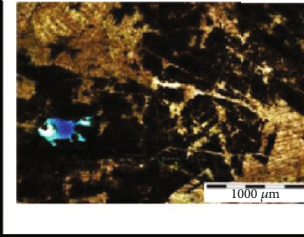 & $x^{2}$ \\
\hline
\end{tabular}

FIGURE 9: Illustration of selected facies and their correlation with the petrographic studies. It is observed that porosity and permeability values are related to specific diagenetic facies (i.e., dolomarble and Dol. II).

of broken, isolated blocks ( $>1 \mathrm{~m}$ in size) of metamorphosed limestone within the intrusive dolerites indicates the intensity of upwelling of magmatic fluids through the studied carbonate successions (Figure 4(a)). These detached, broken blocks of metamorphosed limestone exhibit no reaction with the surrounding igneous material due to the fact that they are marbleized, which made them impervious to the flow of hydrothermal fluids (Figure 4(a) and Table 1). During the emplacement of igneous intrusions, the dolomite phases were formed from the hydrothermal fluids originated from the magma source (Figure 4(b)). The high-temperature origin of these dolomite phases is confirmed by the sharp color contrast and nonplanar crystal habit [62] (Figures 3(c), 4, $5(\mathrm{a})$, and 5(b)). In addition, the presence of hightemperature minerals (i.e., ankerite and diopside) may have resulted from the interaction between hydrothermal fluids with the host limestone, which is also confirmed by various studies where diopside mineral is usually found in skarn deposits [59] (Figures 8(a) and 8(b)).

\subsection{Diagenetic Alterations and Interpreted Paragenetic} Sequence. The detailed paragenetic sequence has been established on the basis of the above-mentioned observations (Figure 12). This includes two stages of diagenetic modifications, which are as follows: (i) Mg-rich, hydrothermal fluids affected the host limestone soon after the magmatic emplacement, which resulted in hydrothermal dolomitisation (Dol. I) as evidenced by field observations and petrographic studies and supported by isotopic signatures, (ii) low-grade contact metamorphism and the formation of marble, and (iii) latestage dolomitisation (Dol. II) before dissolution and dedolomitisation associated with uplift and meteoric recharge.

Dol. I mostly consists of dark grey, massive matrixreplacive dolomite, which exhibits a nonplanar, very coarse crystalline texture (saddle type), and was formed before the intrusion of magmatic material and contact metamorphism of the host limestone, which was later converted into coarse crystalline, twinned marble (Figures 6(e) and 6(f)). Dol. II consists of light brown, sugary textured, fracture-filled dolomite cement, which is medium to coarsely crystalline, whereas intercrystalline pore spaces are filled with detrital clays (Figures 6 and 7). Dol. II developed after the intrusions of the basic dyke as such dolomite postdate twinned marble (Figure 7(a)). In addition, such dolomite (i.e., Dol. II) mostly occurs as fracture and pore fillings in the metamorphosed limestone and the intrusive body, respectively (Figures 6(b) and $6(\mathrm{e}))$. Subsequently, the growth of Dol. II continued resulting in the formation of growth zones in the form of white dolomite cement along crystal boundaries (Figure 7(e)). Dissolution-related porosity in general develops along partially dedolomitised dolomites [63, 64]. Such a phenomenon was also observed in the present study, and Dol. II underwent dedolomitisation (Figure 7(f)).

In summary, the diagenetic evolution of the Ordovician Khyber limestone has close relationship with the intrusive magmatic body of mafic origin, which provided heat and necessary fluids for the diagenesis of the host limestone units. The pervasive, coarse crystalline dolomite (Dol. I) formed 


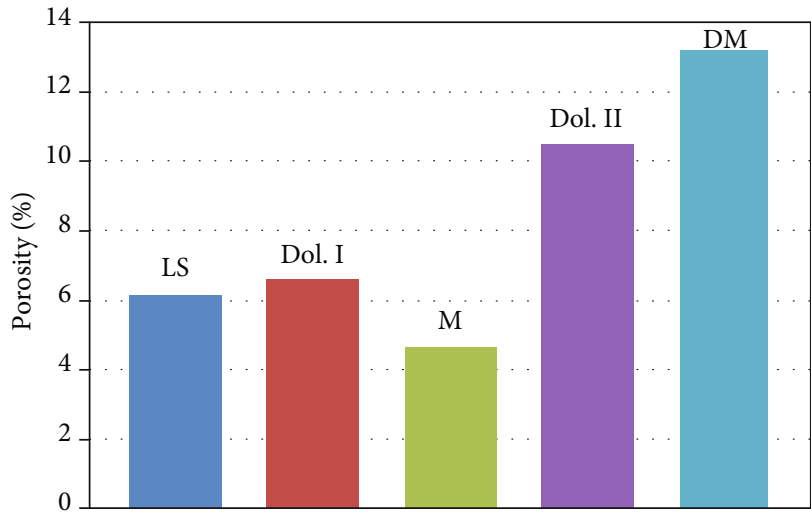

(a)

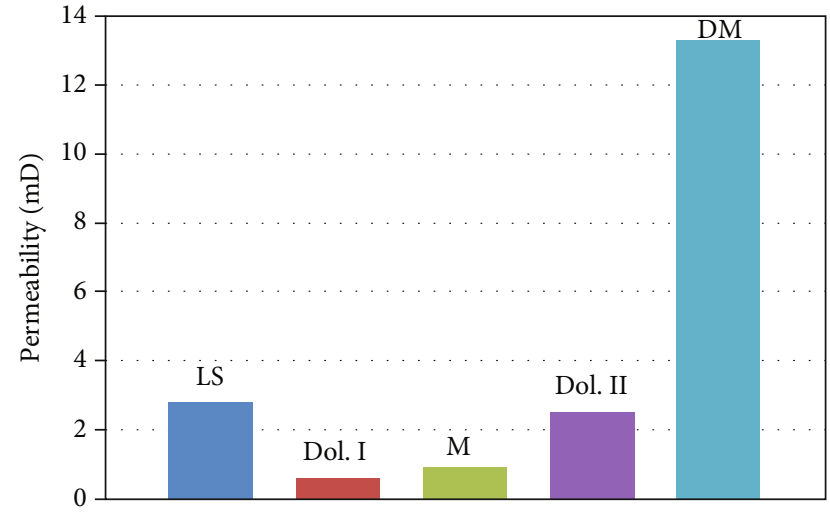

(b)

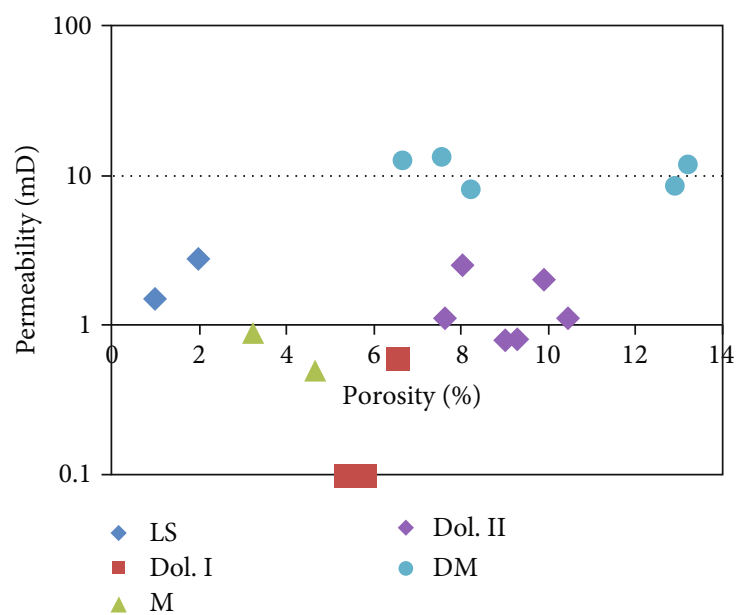

(c)

Figure 10: (a, b) Histograms showing porosity and permeability values of various diagenetic phases observed in Khyber Limestone. (c) Crossplot showing porosity-permeability variation with respect to different diagenetic phases.

during or soon after the emplacement of the magmatic intrusions. The tectonic activation/reactivation and the resulting normal faulting in the area may have provided pathways for Mg-rich fluids of hydrothermal origin. The second episode of dolomitisation resulted from the fracture-filled dolomite (Dol. II) in marble (i.e., dolomite marble) and vein- and fracture-filling dolomite, respectively.

5.2. O/C Isotopic Signatures. Analysis of the cross-plot between $\delta^{13} \mathrm{C}$ and $\delta^{18} \mathrm{O}$ of diagenetic phases of dolomite and calcite following an inverted J pattern, which represents fluid-rock interaction at various stages of diagenesis [65, 66]. In addition, the depleted $\delta^{18} \mathrm{O}$ values of the diagenetic phases indirectly reflect the temperature of the diagenetic fluids $[65,66]$. Oxygen isotope values of the diagenetic phases (Dol. I, marble, Dol. II, and dolomitic marble) reveal depletion of $\delta^{18} \mathrm{O}$ (Figures $8(\mathrm{a})$ and $8(\mathrm{~b})$ ), which may either be due to an increase in temperature and/or $\delta^{18} \mathrm{O}$-depleted fluids as suggested by various studies (e.g., [9, 12, 13, 24, 65-70]). According to Bindeman [71], fluid-rock interaction between host carbonate rock and dyke/magmatic rock results in the depletion of $\delta^{18} \mathrm{O}$ signatures, where dykes are more depleted (i.e., at least $10 \%$ ) in $\delta^{18} \mathrm{O}$ than marine carbonates.
It appears more probable that the investigated dolomites associated with magmatic driven fluids were formed at elevated temperatures. In order to determine the $\delta^{18} \mathrm{O}(\%$ SMOW) fluid composition of Dol. I, Dol. II, M, and DM, the values of $\delta^{18} \mathrm{O}(\mathrm{V}-\mathrm{PDB})$ were plotted against the precipitation temperature by using the fractionation equation of Land [69]. The plot shows that the inferred $\delta^{18} \mathrm{O}$ (\%o SMOW) fluid values of Dol. I and Dol. II are +10.5 and $+10.0 \%$ o (Av. V-SMOW), respectively, showing their origin from magmatic waters (Figure 13). Similarly, the $\delta^{18} \mathrm{O}$ (Av. $\%$ SMOW) fluid signatures of marble $(\mathrm{M})$ and dolomitic marble (DM) are +15.6 and $+13.5 \%$ (Av. V-SMOW), respectively, showing their magmatic origin (Figure 13). Based on the above stated discussion, it is confirmed that various dolomite and marbleized phases are derived from magmatic fluid interaction with the host limestone (Figure $8(\mathrm{~b})$ ). Nevertheless, during the late stages, the area was subjected to uplift due to the Himalayan orogeny, which caused exposure and involvement of surface-derived fluids contaminated by soil$\mathrm{CO}_{2}$, which affected limestone and dolomite units and caused dedolomitisation. This is represented by less depleted $\delta^{18} \mathrm{O}$ and depleted $\delta^{13} \mathrm{C}$ values probably formed near meteoric recharge (Figure 8; e.g., [72-77, 15]). 


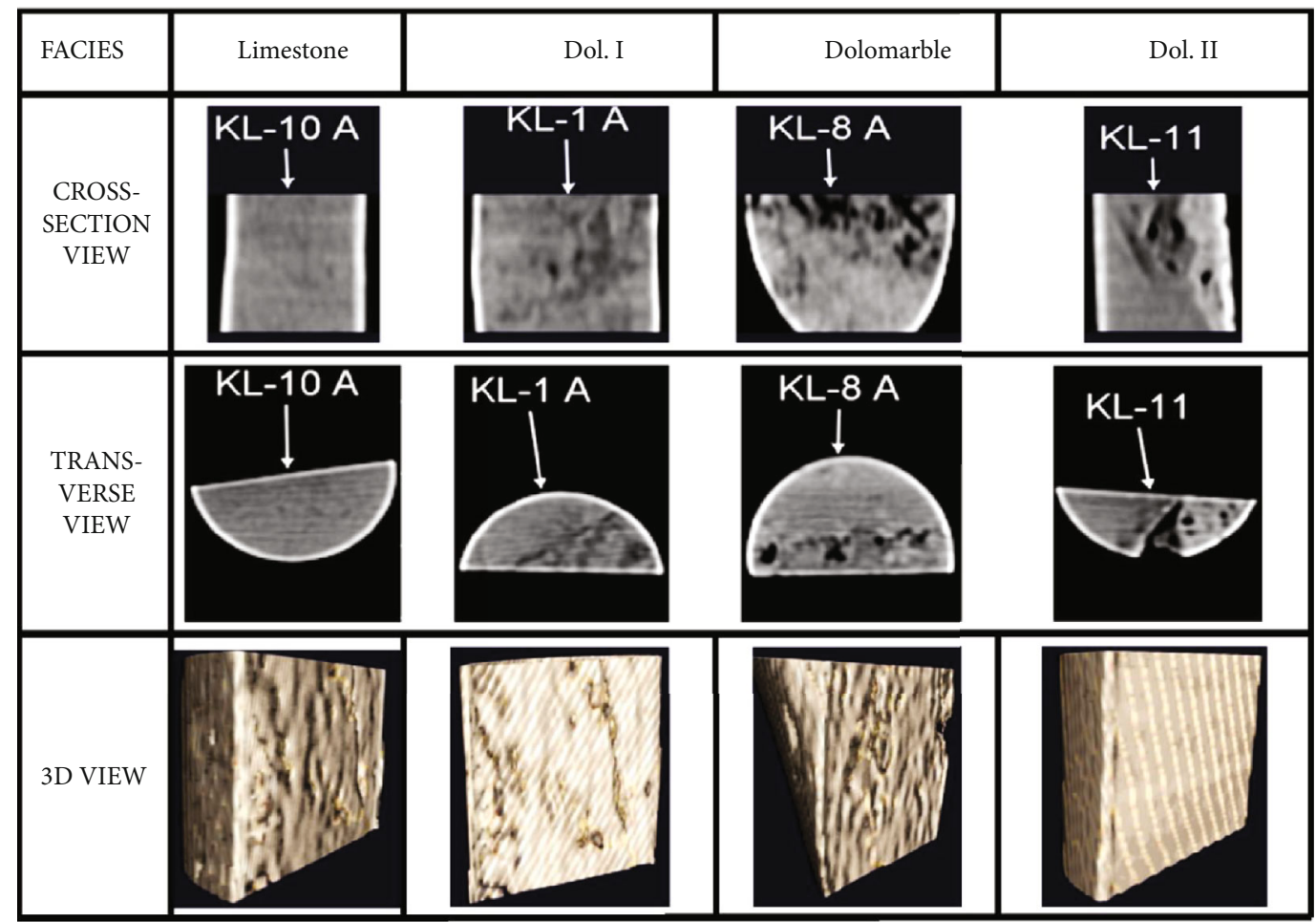

FIGURE 11: Computed tomographic (CT) studies of the selected plug samples representing various diagenetic phases. The first and second rows show the cross-sectional and transverse view of the CT studies. Note that the black spots indicating porosity are significantly higher in the dolomitic marble and Dol. II. The third row shows the 3D view of the selected samples, indicating pore network and their connectivity.

\begin{tabular}{|c|c|c|c|c|}
\hline Diagenetic processes and events & Marine & Burial & Uplift & $\begin{array}{c}\text { Reservoir quality } \\
\text { enhanced/reduced } \\
+/-\end{array}$ \\
\hline $\begin{array}{l}\text { Shallow marine platform sedimentat } \\
\text { Wackstone-packstone limestone }\end{array}$ & & & & \\
\hline Magmatic intrusion & & & & + \\
\hline Fracturing & & & & + \\
\hline Hydrothermal fluids migration & & & & + \\
\hline Dolomite (Dol. I) & & & & - \\
\hline Dolo-marble frmation & & & & - \\
\hline Dolomite (Dol. II) & & & & + \\
\hline Uplift and erosion & & & & + \\
\hline Dissolution by surificial fluids & & & & + \\
\hline Dedolomitization & & & & + \\
\hline
\end{tabular}

FIGURE 12: Paragenetic sequence showing various diagenetic phases within the carbonate succession and its relationship with the evolution of petrophysical properties. 


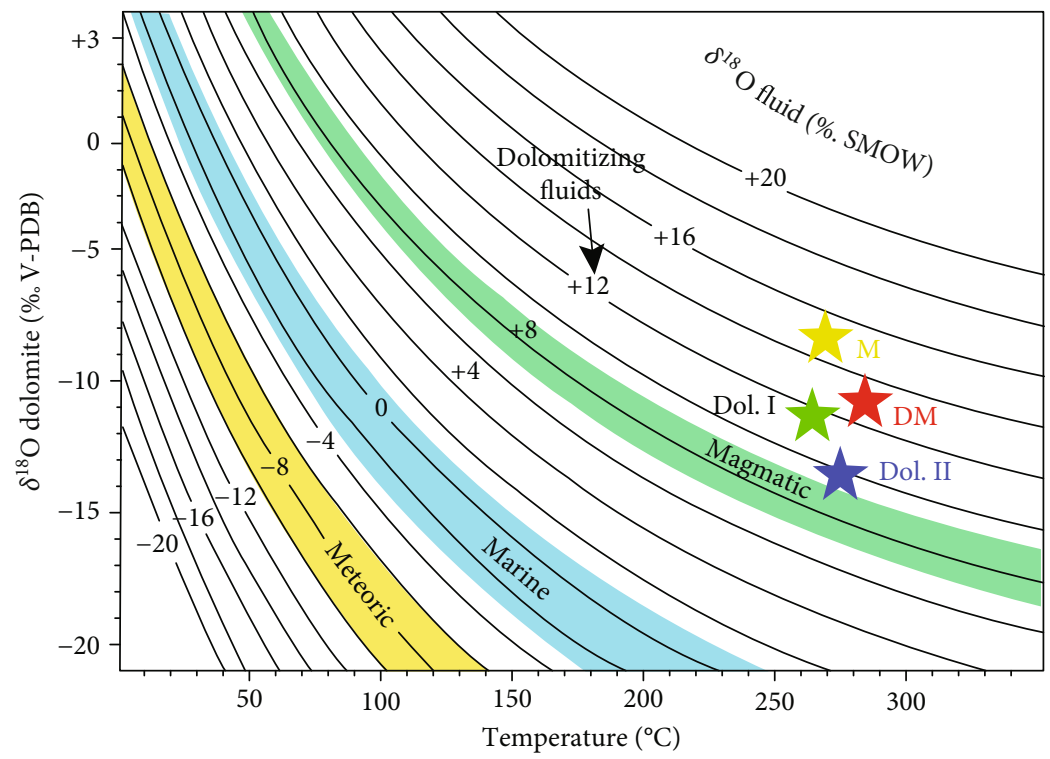

FIGURE 13: The average precipitation temperature versus oxygen isotopic composition of the analyzed carbonate phases. The star shows their mean values of the observed diagenetic phases. (a) The $\delta^{18} \mathrm{O}$ of the fluid in equilibrium with inferred values of dolomite (Dol. I, Dol. II), marble (M), and dolomitic marble (DM) was calculated using the fractionation equation of Land [69]. Meteoric water [76]. Marine water [77]. Magmatic water [78].

\subsection{Influence of Diagenetic Alterations on Reservoir} Properties. Diagenetic changes had both positive and negative effects on the reservoir properties of the host rock ([79]; Figure 12). Early dolomitisation (Dol. I) associated with Mg-rich hydrothermal fluids resulted in a replacive phase and had less effect on porosity modification in the host limestone. This was followed by the emplacement of dolerite intrusions resulting in recrystallization due to contact metamorphism, further reducing the porosity (marble) (Figure 10(a)). However, in fracture development and latestage dolomitisation (Dol. II), postdating magmatic emplacement resulted in considerable enhancement of porosity and permeability (Figure 10(a)).

The second dolomite phase (i.e., fracture and pore-filled; Dol. II) contributed to the reservoir properties of the studied carbonates by retaining secondary porosity and intercrystalline pore spaces within Dol. II, which significantly enhanced the pore network (up to $13 \%$ porosity; Figures 6(e), 10(a), and 11). Dol. II comprises most of the dolomite in the study area, and the reservoir properties of the studied rocks are therefore enhanced through Dol. II. In addition, fractures as well as dissolution seams further enhanced the pore networks (Figure 6(f)). Uplift and exposure resulted in a meteoric influx that caused dedolomitisation of the dolomite phases observed (Figures 10(a) and 12).

Various diagenetic phases played a significant role in controlling the reservoir characteristics of the studied rocks. An increase in the content of Dol. II increased the pore space and contributed to porosity enhancement (Figure 10(b)). However, Dol. I shows low porosity due to the nonplanar nature of crystals and presents occluded pore spaces by clays (Figure 10(b)). A progressive increase in porosity was observed in the dolomite marble, in which fracture-filled Dol. II forms a major part of the analyzed samples. In sum- mary, marble with less fracture-filled dolomite (i.e., Dol. II) showed low porosity values, compared to marbles consisting of more than $80 \%$ Dol. II which had elevated porosity values (Figure 10(a)).

Porosity and permeability studies are further validated by microtomography, where the high intensity of microfracture development and high rate of interconnectivity confirm high porosity and permeability values in the dolomarble phase (i.e., up to $\theta=15 \% ; k=14 \mathrm{mD}$ ) (Figures 10(a) and 11). Dol. II exhibits relatively high porosity (up to $10 \%$ ) and low permeability (up to $2 \mathrm{mD}$ ) due to the moderate nature of fracture distribution but negligible pore connectivity (Figures 10(a) and 11). In contrast, the low microfracture development and interconnectivity of pore spaces justify less porosity and permeability values in the precursor limestone, saddle dolomite Dol. I, and marble (i.e., up to $\theta=5 \% ; k=2 \mathrm{mD}$ ) (Figures 10(a) and 11). This leads to the conclusion that the host limestone, nonplanar dolomite (Dol. I), and marbles acted as barriers to fluid migration, whereas dolomite marble and fracture-filling dolomite (Dol. II) contributed to the enhancement of reservoir properties in the studied rocks (Figures 5 and 12). This leads to the suggestion that postmarble tectonic activity resulted in brittle deformation and the corresponding fractures were filled by Dol. II, hence retaining considerable intercrystalline porosity as evidenced in Figure 6(e).

\section{Conclusions}

This excellent outcrop analogue shows the effect of igneous intrusions on the reservoir behavior of a carbonate succession, whereby modifying the mineralogical composition of the host limestone due to the associated fluid-rock 
interaction. The key conclusions from the present study are as follows:

(i) Field observations reveal that hydrothermal fluid emplacement followed by igneous intrusions of basic origin in the host limestone resulted in dolomitisation and transformation of limestone to marble

(ii) Sharp contacts between the intrusive bodies and host limestones and the presence of isolated limestone clasts of variable sizes suggest a rapid interaction of the magmatic fluids with the host limestone

(iii) Two distinct dolomite phases, which postdate magmatic intrusions, have been reported. The first phase of dolomitisation resulted in matrix-replacive saddle dolomite, whereas the second-phase dolomites are mostly found as fracture and/or pore fillings. Dedolomitisation, dissolution, and infilling of meteoric calcite mark the end of the diagenetic history

(iv) The first-phase saddle dolomite cement (Dol. I), related to the hydrothermal fluids, mostly occluded the pore space and negatively impacted the reservoir properties. The second-phase pore-filling dolomite (Dol. II) forms the major part of the diagenetic stage and exhibits good porosity $(\sim 15 \%)$ and permeability values, hence making them potential reservoirs with considerable fracture density and interconnected pore network. Fracture development after the magmatic intrusion resulted in porosity enhancement and infilling of Dol. II. Dedolomitisation followed by dissolution-related phenomenon affected the second phase of dolomite and hence generated late dissolution-related porosity

(v) The $\delta^{18} \mathrm{O}$ and $\delta^{13} \mathrm{C}$ isotope fractionation trajectories suggest that the dolomites were formed at a temperature between $150^{\circ} \mathrm{C}$ and $340^{\circ} \mathrm{C}$ from the hotter fluids that interacted with the regional limestone. The source of dolomitizing fluids is probably from the magmatic intrusion. Later on, the surfaceweathering agents caused enrichment in $\delta^{18} \mathrm{O}$ and $\delta^{13} \mathrm{C}$ values of the early formed phases

(vi) Correlation of petrographic and porosity-permeability studies revealed that reservoir properties are associated with specific diagenetic phases. Computed tomography (CT) further confirmed the porosity-permeability results and helped to understand the porositypermeability evolution in various diagenetic phases.

\section{Data Availability}

Field data acquired from outcrop has been analyzed and interpreted using techniques mentioned in "Materials and Methods."

\section{Conflicts of Interest}

The authors declare that they have no conflicts of interest.

\section{Acknowledgments}

Funding for this research was received from the University Research Fund (2016). The authors wish to thank Frontier Constabulary, Peshawar, for providing security during field visits. We are indebted to Geology \& Reservoir (G\&R) Laboratory of Oil \& Gas Development Company Limited (OGDCL) for poropermeability analyses. We are also grateful to Geosciences Advance Research Laboratory (GARL), Geological Survey of Pakistan (GSP), for performing XRD analyses.

\section{References}

[1] S. A. Reeckmann and A. J. Mebberson, "Igneous intrusions in the north-west Canning Basin and their impact on oil exploration," in The Canning Basin, Western Australia. Proceedings of the Geological Society of Australia/Petroleum Exploration Society of Australia Canning Basin Symposium, pp. 389-399, Perth, WA, 1984.

[2] X. Wang, I. Lerche, and C. Walters, "The effect of igneous intrusive bodies on sedimentary thermal maturity," Organic Geochemistry, vol. 14, no. 6, pp. 571-584, 1989.

[3] A. N. Bishop and G. D. Abbott, "Vitrinite reflectance and molecular geochemistry of Jurassic sediments: the influence of heating by Tertiary dykes (northwest Scotland)," Organic Geochemistry, vol. 22, no. 1, pp. 165-177, 1995.

[4] S. R. Schutter, "Hydrocarbon occurrence and exploration in and around igneous rocks," Geological Society London Special Publications, vol. 214, no. 1, pp. 7-33, 2003.

[5] N. Petford and K. McCaffrey, "Hydrocarbons in crystalline rocks: an introduction," Geological Society, London, Special Publications, vol. 214, no. 1, pp. 1-5, 2003.

[6] M. Y. Farooqui, H. Hou, G. Li et al., "Evaluating volcanic reservoirs," Oilfield Review, vol. 21, pp. 36-47, 2009.

[7] C. Jacquemyn, H. el Desouky, D. Hunt, G. Casini, and R. Swennen, "Dolomitization of the Latemar platform: fluid flow and dolomite evolution," Marine and Petroleum Geology, vol. 55, pp. 43-67, 2014.

[8] K. Xu, B. Yu, H. Gong, Z. Ruan, Y. Pan, and Y. Ren, "Carbonate reservoirs modified by magmatic intrusions in the Bachu area, Tarim Basin, NW China," Geoscience Frontiers, vol. 6, no. 5, pp. 779-790, 2015.

[9] M. Boni, G. Parente, T. Bechstädt, B. de Vivo, and A. Iannace, "Hydrothermal dolomites in SW Sardinia (Italy): evidence for a widespread late-Variscan fluid flow event," Sedimentary Geology, vol. 131, no. 3-4, pp. 181-200, 2000.

[10] M. Antonellini and P. N. Mollema, "A natural analog for a fractured and faulted reservoir in dolomite: Triassic Sella Group, northern Italy," American Association of Petroleum Geologists Bulletin, vol. 84, pp. 314-344, 2000.

[11] A. M. Wilson, W. Sanford, F. Whitaker, and P. Smart, "Spatial patterns of diagenesis during geothermal circulation in carbonate platforms," American Journal of Science, vol. 301, no. 8, pp. 727-752, 2001.

[12] M. Gasparrini, T. Bechstadt, and M. Boni, "Massive hydrothermal dolomites in the southwestern Cantabrian Zone (Spain) and their relation to the Late Variscan evolution," Marine and Petroleum Geology, vol. 23, no. 5, pp. 543-568, 2006.

[13] G. J. Davies and L. B. Smith, "Structurally controlled hydrothermal dolomite reservoir facies: an overview," American 
Association of Petroleum Geologists Bulletin, vol. 90, no. 11, pp. 1641-1690, 2006.

[14] A. Koeshidayatullah, H. Corlett, J. Stacey et al., "Evaluating new fault-controlled hydrothermal dolomitization models: insights from the Cambrian Dolomite, Western Canadian Sedimentary Basin," Sedimentology, vol. 67, pp. 2945-2973, 2020.

[15] F. H. Nader, R. Swennen, and E. Keppens, "Calcitization/dedolomitization of Jurassic dolostones (Lebanon): results from petrographic and sequential geochemical analyses," Sedimentology, vol. 55, no. 5, pp. 1467-1485, 2008.

[16] J. Conliffe, K. Azmy, S. A. Gleeson, and D. Lavoie, "Fluids associated with hydrothermal dolomitization in St. George Group, western Newfoundland, Canada," Geofluids, vol. 10, no. 3, p. $437,2010$.

[17] J. Dewit, A. Foubert, H. A. El Desouky et al., "Characteristics, genesis and parameters controlling the development of a large stratabound HTD body at Matienzo (Ramales Platform, Basque-Cantabrian Basin, northern Spain)," Marine and Petroleum Geology, vol. 55, pp. 6-25, 2014.

[18] J. P. Hendry, J. M. Gregg, K. L. Shelton, I. D. Somerville, and S. F. Crowley, "Origin, characteristics and distribution of fault-related and fracture-related dolomitization: insights from Mississippian carbonates, Isle of Man," Sedimentology, vol. 62, no. 3, pp. 717-752, 2015.

[19] T. D. Gilbert, L. C. Stephenson, and R. P. Philp, "Effect of a dolerite intrusion on triterpane stereochemistry and kerogen in Rundle oil shale, Australia," Organic Geochemistry, vol. 8, no. 2, pp. 163-169, 1985.

[20] J. L. Clayton and N. H. Bostick, “Temperature effects on kerogen and on molecular and isotopic composition of organic matter in Pierre Shale near an igneous dike," Organic Geochemistry, vol. 10, no. 1-3, pp. 135-143, 1986.

[21] P. Sruoga and N. Rubinstein, "Processes controlling porosity and permeability in volcanic reservoirs from the Austral and Neuquén basins Argentina," American Association of Petroleum Geologists Bulletin, vol. 91, no. 1, pp. 115-129, 2007.

[22] R. Rateau, N. Schofield, and M. Smith, "The potential role of igneous intrusions on hydrocarbon migration, West of Shetland," Petroleum Geoscience, vol. 19, no. 3, pp. 259-272, 2013.

[23] B. Alalade and R. V. Tyson, "Influence of igneous intrusions on thermal maturity of Late Cretaceous shales in the Tuma well, Chad Basin, NE Nigeria," Journal of African Earth Sciences, vol. 77, pp. 59-66, 2013.

[24] M. M. Shah, F. H. Nader, D. Garcia, R. Swennen, and R. Ellam, "Hydrothermal dolomites in the Early Albian (Cretaceous) platform carbonates (NW Spain): nature and origin of dolomites and dolomitising fluids," Oil \& Gas Science and Technology Revue d'IFP Energies nouvelles, vol. 67, no. 1, pp. 97-122, 2012.

[25] S. Dong, D. Chen, H. Qing et al., "Hydrothermal alteration of dolostones in the Lower Ordovician, Tarim Basin, NW China: multiple constraints from petrology, isotope geochemistry and fluid inclusion microthermometry," Marine and Petroleum Geology, vol. 46, pp. 270-286, 2013.

[26] E. S. Falk and P. B. Kelemen, "Geochemistry and petrology of listvenite in the Samail ophiolite, Sultanate of Oman: complete carbonation of peridotite during ophiolite emplacement," Geochimica et Cosmochimica Acta, vol. 160, pp. 70-90, 2015.

[27] H. G. Machel and J. Lonnee, "Hydrothermal dolomite - a product of poor definition and imagination," Sedimentary Geology, vol. 152, pp. 163-171, 2002.
[28] D. Cantrell, P. K. Swart, R. C. Handford, C. G. Kendall, and H. Westphal, "Geology and production significance of dolomite trends, Arab-D reservoir, Ghawar Field, Saudi Arabia:," Geo-Arabia, vol. 6, pp. 45-60, 2004.

[29] M. Sudrie, B. Caline, M. A. López-Horgue, P. A. FernándezMendiola, and E. Iriarte, "Fault-related hydrothermal dolomites in Cretaceous platform carbonates from the Karrantza area (North Spain): outcrop analog for dolomite reservoir characterization," in 7th Middle East geoscience conference and exhibition, Bahrain, 2006.

[30] P. Ronchi, A. Ortenzi, O. Borromeo, M. Claps, and W. G. Zempolich, "Depositional setting and diagenetic processes and their impact on the reservoir quality in the late ViseanBashkirian Kashagan carbonate platform (Pre-Caspian Basin, Kazakhstan)," AAPG Bulletin, vol. 94, no. 9, pp. 1313-1348, 2010.

[31] F. H. Nader, M. A. Lopéz-Horgue, M. M. Shah et al., "The Ranero hydrothermal dolomites (Albian, Karrantza valley, northwestern Spain): Implications on conceptual dolomite models," Oil and Gas Science and Technology Revu de l'IFP Energies nouvelles, vol. 67, no. 1, pp. 09-30, 2012.

[32] R. Swennen, J. Dewit, E. Fierens et al., "Multiple dolomitization events along the Pozalagua Fault (Pozalagua Quarry, Basque-Cantabrian Basin, Northern Spain)," Sedimentology, vol. 59, pp. 1345-1374, 2012.

[33] F. Lapponi, T. Bechstädt, M. Boni, D. A. Banks, and J. Schneider, "Hydrothermal dolomitization in a complex geodynamic setting (Lower Palaeozoic, northern Spain)," Sedimentology, vol. 61, no. 2, pp. 441-443, 2013.

[34] V. Vandeginste, C. M. John, J. W. Cosgrove, and C. Manning, "Dimensions, texture distribution and geochemical heterogeneities of fracture-related dolomite geobodies hosted in Ediacaran limestones northern Oman," AAPG Bulletin, vol. 98, no. 9, pp. 1789-1809, 2014.

[35] D. Zhu, Q. Meng, Z. Jin, Q. Liu, and W. Hu, "Formation mechanism of deep Cambrian dolomite reservoirs in the Tarim basin, northwestern China," Marine and Petroleum Geology, vol. 59, pp. 232-244, 2015.

[36] A. Khan, M. Aslam, and R. N. Khan, "Revised stratigraphy of the Paleozoic rocks, Khyber Agency, NWFP, Pakistan," Geological Survey of Pakistan, vol. 431, pp. 1-11, 1989.

[37] K. Pogue, B. Wardlaw, A. G. Harris, and A. Hussain, "Paleozoic and Mesozoic stratigraphy of the Peshawar basin, Pakistan: correlations and implications," Geological Society of America Bulletin, vol. 104, no. 8, pp. 915-927, 1992.

[38] J. Boulin, "Hercynian and Eocimmerian events in Afghanistan and adjoining regions," Tectonophysics, vol. 148, pp. 253-278, 1988.

[39] R. A. K. Tahirkheli, "Geology of Kohistan and adjoining area Eurasian and Indo-Pakistan continents, Pakistan: Geological Bulletin," University of Peshawar (Special Issue), vol. 15, pp. 1-51, 1979.

[40] P. Patriat and J. Achache, "India-Eurasia collision chronology has implications for crustal shortening and driving mechanism of plates," Nature, vol. 311, pp. 615-621, 1984.

[41] M. P. Searle, B. F. Windley, M. P. Coward et al., "The Closing of Tethys and the tectonics of the Himalaya," Geological Society of America Bulletin, vol. 98, no. 6, pp. 678-701, 1987.

[42] J. F. Dewey, S. Cande, and W. C. Pitman, “Tectonic evolution of the India-Eurasia collision zone," Eclogae Geologicae Helvetiae, vol. 82, pp. 717-734, 1989. 
[43] C. T. Klootwijk, J. S. Gee, J. W. Peirce, and G. M. SmithConstraints on the India-Asia convergence: paleomagnetic results from Ninety-east Ridge," Proceedings, ODP, Science Results, J. Weissel, J. Peirce, E. Taylor, and J. Alt, Eds., , pp. 777-882, 1991.

[44] X. Le Pichon, M. Fournier, and L. Jolivet, "Kinematics, topography, shortening, and extrusion in the India- Eurasia collision," Tectonics, vol. 11, pp. 1085-1098, 1992.

[45] D. B. Rowley, "Age of collision between India and Asia: a review of the stratigraphic data," Earth and Planetary Science Letters, vol. 145, pp. 1-13, 1996.

[46] A. Yin and T. M. Harrison, "Geologic evolution of the Himalayan-Tibetan orogen," Annual Review of Earth and Planetary Sciences, vol. 28, pp. 211-280, 2000.

[47] B. Zhu, W. S. F. Kidd, D. B. Rowley, B. S. Currie, and N. Shafique, "Age of initiation of the India-Asia collision in the east central Himalaya," Journal of Geology, vol. 113, pp. 265-285, 2005.

[48] S. Heuberger, U. Schalteggar, J. P. Burg et al., "Age and isotopic constraints on magmatism along the Karakoram-Kohistan suture zone, NW-Pakistan: evidence for subduction and continued convergence after India-Asia collision," Eclogae Geologicae Helvetiae, vol. 1, no. 1, pp. 1-24, 2007.

[49] J. C. Aitchison, J. R. Ali, and A. M. Davis, "When and where did India and Asia collided?," Journal of Geophysical Research, vol. 112, pp. 05-23, 2007.

[50] S. D. Khan, D. J. Walker, S. A. Hall, K. C. Burke, M. T. Shah, and M. Lisa, "Did the Kohistan-Ladakh island arc collide first with India?," Geological Society of America Bulletin, vol. 9, no. 121, pp. 366-384, 2009.

[51] R. A. K. Tahirkheli, M. Mattauer, F. Proust, and P. Tapponnier, "The India-Eurasia suture zone in northern Pakistan: synthesis and interpretation of recent data at plate scale," in Geodynamics of Pakistan, A. Farah and K. A. Jong, Eds., pp. 125-130, Geological Survey of Pakistan, 1979.

[52] A. H. Kazmi and M. Q. Jan, Geology and Tectonics of Pakistan, Graphic Publishers, Karachi, 1997.

[53] S. M. I. Shah, "Precambrian and Paleozoic of Pakistan," in Stratigraphy of Pakistan, S. M. I. Shah, Ed., vol. 12, pp. 1-5, Geological Survey of Pakistan, Memoir, 2009.

[54] S. M. I. Shah, R. A. Siddiqui, and J. A. Talent, Geology of the Eastern Khyber Agency, North Western Frontier Province, Pakistan, vol. 44, Geological Survey of Pakistan, 1980.

[55] M. P. Searle and P. J. Treloar, "Was late cretaceous-Paleocene obduction of ophiolite complexes the primary cause of crustal thickening and regional metamorphism in the Pakistan Himalaya?," Geological Society Special Publication, vol. 338, no. 1, pp. 345-359, 2010.

[56] M. A. Khan, "Siluro-Devonian reef complex of Ghundai Sar and vicinity," Jamrud, Khyber Agency: Peshawar Univetsity Geological Bulletin, vol. 4, pp. 79-82, 1969.

[57] D. F. Sibley and J. M. Gregg, "Classification of dolomite rock textures," Journal of Sedimentary Petrology, vol. 57, pp. 967975, 1987.

[58] E. A. Wachter and J. M. Hayes, "Exchange of oxygen isotopes in carbon dioxide-phosporic acid systems," Chemical Geology: Isotope Geoscience section, vol. 52, no. 3-4, pp. 365-374, 1985.

[59] J. Rosenbaum and S. M. F. Sheppard, "An isotopic study of siderites, dolomites and ankerites at high temperatures," Geochimica et Cosmochimica Acta, vol. 50, no. 6, pp. 1147-1150, 1986.

[60] R. A. Ketcham and W. D. Carlson, "Acquisition, optimization and interpretation of X-ray computed tomographic imagery: applications to the geosciences," Computers \& Geosciences, vol. 27, pp. 381-400, 2001.

[61] J. Veizer, D. Ala, K. Azmy, P. Bruckschen, and D. Buhl, " $87 \mathrm{Sr} / 86 \mathrm{Sr}, \delta 13 \mathrm{C}$ and $\delta 18 \mathrm{O}$ evolution of Phanerozoic seawater," Journal of Chemical Geology, vol. 161, no. 1-3, pp. 5988, 1999.

[62] A. Koeshidayatullah, H. Corlett, J. Stacey, P. K. Swart, A. Boyce, and C. Hollis, "Origin and evolution of faultcontrolled hydrothermal dolomitization fronts: a new insight," Earth and Planetary Science Letters, vol. 541, article 116291, 2020.

[63] C. O. Karacan, A. S. Grader, and P. M. Halleck, "Evaluation of local porosity changes in limestone samples under triaxial stress field by using X-ray computed tomography," in Applications of X-ray Computed Tomography in the Geosciences, F. Mees, R. Swennen, M. Geet, and P. Jacobs, Eds., vol. 215, pp. 177-189, Geological Society London, Special Publications, 2003.

[64] P. M. Silverman, C. J. Cooper, D. I. Weltman, and R. K. Zeman, "Helical CT: practical considerations and potential pitfalls," Radio Graphics, vol. 15, pp. 25-36, 1995.

[65] J. R. Allan and W. D. Wiggins, Dolomite reservoirs, vol. 36 of Geochemical techniques for evaluating origin and distribution: AAPG Continuing Education Course Notes Series, 1993.

[66] P. K. Swart, "The geochemistry of carbonate diagenesis: the past present and future," Sedimentology, vol. 62, no. 5, pp. 1233-1304, 2015.

[67] M. Shah and W. Ahmed, "Enhanced reservoirs through selective dissolution of fault-related dolostone (Upper Albian), NW Spain," in 8th Workshop of the ILP-Task Force Sedimentary Basin, "Lithosphere Dynamics and Sedimentary Basins: The Circum-Mediterranean Basins and Analogues", Marseille, France, 2013.

[68] B. M. Radke and R. L. Mathis, "On the formation and occurrence of saddle dolomites," Journal of Sedimentary Research, vol. 50, no. 4, pp. 1149-1168, 1980.

[69] L. S. Land, "The application of stable isotopes to studies of the origin of dolomite and to problems of diagenesis of clastic sediments," in Stable isotopes in sedimentary geology, M. A. Arthur and T. F. Anderson, Eds., no. 10pp. 4.1-4.22, SEPM Short Course, 1983.

[70] C. Spötl and J. K. Pitman, "Saddle (baroque) dolomite in carbonates and sandstones: A re-appraisal of a burial-diagenetic concept," in Carbonate Cementation in Sandstones: Distribution Patterns and Geochemical Evolution, vol. 26, pp. 437460, IAS Special Publication, 1998.

[71] I. N. Bindeman, "Oxygen isotopes in mantle and crustal magmas as revealed by single crystal analysis," Reviews in Mineralogy and Geochemistry, vol. 69, pp. 445-478, 2008.

[72] J. C. Niemann and J. F. Read, "Regional cementation from unconformity-recharge aquifer and burial fluids, Mississipian Newman Limestone Kentucky," Journal of Sedimentary Petrology, vol. 58, pp. 688-705, 1988.

[73] P. W. Choquette and N. P. James, "Introduction," in Paleokarst, N. P. James and P. W. Choquette, Eds., pp. 1-21, Springer-Verlag, New York, 1988.

[74] R. J. Reeder, "An over-view of zoning in carbonate minerals," in Luminescence Microscopy and Spectroscopy: Qualitative and Quantitative Aspects, C. E. Baker and O. C. Kopp, Eds., vol. 25, pp. 77-82, SEPM Short Course, 1991.

[75] W. J. Meyers, "Calcite cement stratigraphy," in Luminescence Microscopy and Spectroscopy: Qualitative and Quantitative 
Aspects, C. E. Baker and O. C. Kopp, Eds., vol. 25, pp. 133-148, SEPM Short Course, 1991.

[76] F. Tornos, A. Delgado, C. Casquet, and C. Galindo, “300 million years of episodic hydrothermal activity: stable isotope evidence from hydrothermal rocks of the Eastern Iberian Central System," Mineralium Deposita, vol. 35, pp. 551-569, 2000.

[77] E. L. Grossman, "The carbon and oxygen isotope record during the evolution of Pangea: carboniferous to Triassic," in Pangea: Paleoclimate, Tectonics, and Sedimentation during Accretion, Zenith and Breakup of a Supercontinent, G. D. Klein, Ed., vol. 288, pp. 207-228, Geological Society of America Special Paper, 1994.

[78] D. Arcos, The Mineralizations Associated with Granodiorite in the Cu-Au de Carle's Deposit, Asturias, [Ph.D. thesis], University of Barcelona, Spain, 1996.

[79] C. H. Moore and W. J. Wade, Carbonate Reservoirs: Porosity and Diagenesis in a Sequence Stratigraphic Framework, Newnes, 2013. 